\title{
Partial recall: differences between actual and self-reported annuitization decisions in Sweden
}

\author{
Johannes Hagen \\ Jönköping International Business School, Jönköping University, Jönköping, Sweden \\ Corresponding author. Email: johannes.hagen@ju.se
}

(Received 7 May 2019; revised 4 September 2020; accepted 2 October 2020; first published online 11 January 2021)

\begin{abstract}
This paper reports the results from a large telephone survey of 1,000 retiring white-collar workers in Sweden. Shortly before the interview, the participants at age 65 had a choice of receiving a life annuity by default or opting for a fixed-term payout, with a minimum payout length of 5 years. Large monetary amounts were at stake in the payout decision of the survey participants; the average monthly pension payment under the life annuity amounted to US $\$ 280$. Comparing the survey responses with administrative records on actual payout choices, I find that a majority of retiring white-collar workers fail to recall their payout decision. The recollection rate is much lower among annuitants (those who chose the default option); only $40 \%$ of the annuitants accurately recalled their payout decision compared to $77 \%$ of those who opted for a fixed-term payout. Beyond payout choice, few individual characteristics predict successful recollection.
\end{abstract}

Keywords: Annuity; occupational pension; retirement; fixed-term payout; term certain annuity

JEL classification: D91; G41; J26; J32

\section{Introduction}

The ongoing shift in pension provision from defined benefit (DB) to defined contribution (DC) has brought more flexibility to the decumulation phase of retirement. Many occupational and private pension plans in developed countries now offer lump-sum payments or phased withdrawals as an alternative to annuitization. Liquid payout options allow individuals to invest, buy an annuity, leave bequests, or increase consumption during the early years of retirement. However, there are concerns that they may trigger individuals to spend the money too rapidly for their own good (Barr and Diamond, 2008).

In Sweden, annuitization rates have been falling as both the share of second-pillar pension wealth that is not subject to mandatory annuitization and awareness of alternative payouts have increased. Between 2008 and 2015, annuitization rates in several major pension plans fell from well above $80 \%$ to $60-65 \%$ (Hagen, 2015, 2017b); more recent estimates suggest that these shares are now below 50\% (AMF, 2018). This resembles the situation in US DB pension plans where annuitization rates range from 25\% to 50\% (Mottola and Utkus, 2007; Benartzi et al., 2011; Banerjee, 2013; Previtero, 2014; Park and Banerjee, 2020).

This paper reports the results from a large telephone survey of 1,000 Swedish retirees. Shortly before the survey, these retirees had made a decision on whether to annuitize a substantial fraction of their pension wealth. The survey sample is drawn from the population of Swedish white-collar workers studied in Hagen (2015). In Swedish occupational pension plans, individuals can choose between a life annuity - the default option - and several phased payouts, which are referred to as 
fixed-term payouts. ${ }^{1}$ In the fixed-term payout option, the individual specifies the time period over which the pension capital is withdrawn. The fastest rate at which the pension capital can be withdrawn is 5 years. ${ }^{2}$ If no action is taken, the pension is paid out as a life annuity at age 65. Large monetary amounts were at stake in the payout decision of the survey participants; the average monthly pension payment under the life annuity amounted to US\$280. The survey data are matched with administrative data from the managing pension company; the administrative data include information on the survey participants' actual payout choice. $^{3}$

The lack of comprehensive and reliable data has been one of the main limiting factors in the empirical literature on annuity demand. Some previous studies rely on administrative data from individual pension companies or pension plan administrators (Bütler and Teppa, 2007; Benartzi et al., 2011; Chalmers and Reuter, 2012; Previtero, 2014; Hagen, 2015; Bütler et al., 2017, 2013; Park and Banerjee, 2020). While such data contain information on actual payout choices and, in some cases, also individual characteristics, there is no information on the retirement savers' own reports of their payout decision (or the reasons thereof). Another group of studies use survey-based data, which rely on payout choices that are either hypothetical (Beshears et al., 2014; Agnew et al., 2015, 2008; Knoller, 2016; Bockweg et al., 2018) or self-reported (Brown, 2001; Inkmann et al., 2011; Cappelletti et al., 2013; Banks et al., 2015; Lee, 2016). On the positive side, surveys can ask questions that directly measure specific preferences, and examine choices in economic environments that differ from the current one. On the negative side, hypothetical payout choices may not correspond to the choices that people would make in real-life settings. There is also a risk that individuals' self-reports of past or planned payout choices do not correspond to what they actually chose or will choose. To my knowledge, this is the first study that combines survey data with administrative records of actual payout choices. ${ }^{4}$

Access to actual payout choices provides a unique opportunity to examine ex-post the degree to which retirees accurately recall their payout decisions. Individuals are typically faced with annuitization decisions only once or twice in their lifetimes. The inability to accurately recall their payout decisions may have adverse effects on individual welfare. For example, individuals who operate under the assumption that he or she is receiving a life annuity when, in fact, the payment will end in 5 years may experience an unexpected fall in income. Knowledge of the characteristics of those who have misbeliefs about the length of their payouts, and whether such misbeliefs are related to the choice of payout option, can be used by policymakers and pension plan administrators to design more efficient information interventions and/or choice architecture to prevent feelings of regret among retirees.

The main finding of this paper is that a majority of the retiring workers fail to recall whether they chose a life annuity or a fixed-term payout and that the recollection rate differs significantly by payout choice. Specifically, one-third of the annuitants believe they have a fixed-term payout, and only $40 \%$ (correctly) reported having a life annuity. Of those who opted out of the life annuity, $77 \%$ correctly reported that they have a fixed-term payout. Beyond payout choice, however, few individual characteristics are significantly correlated with an accurate recollection of past payout decisions.

\footnotetext{
${ }^{1} \mathrm{~A}$ fixed-term payout is also known as 'years certain annuity,' 'annuity certain,' or 'term certain annuity.'

${ }^{2}$ In general, there are three main options for allocating accumulated pension assets: lump-sum payments, programmed withdrawals, and annuities. There are also combined arrangements that may involve any combination of these three. The fixed-term payouts studied in this paper fall into the category of programmed withdrawals. Under programmed withdrawals, individuals choose a schedule of periodic fixed or variable payments, where payments are determined by dividing the capital by a fixed number of years or by the expected life expectancy in each period (Antolin, 2008).

${ }^{3}$ There are several recent studies on payout decisions in second-pillar pension plans in Sweden. These studies combine administrative data from the companies that manage these pensions with longitudinal information on individual characteristics from Statistics Sweden; see, for example, ISF $(2015,2017,2018)$, Hagen $(2015,2017 b)$ and Hagen et al. (2018). A related study by Palmer and Larsson (2011) focuses on payout decisions in private pension saving accounts (i.e., the third pillar).

${ }^{4}$ See Alexandrova and Gatzert (2019) for a review of the theoretical, empirical, and experimental evidence on annuitization decisions. Most empirical studies relate their findings to the apparent 'annuity puzzle' - the discrepancy between the high annuitization rates predicted by theoretical models (e.g., Yaari (1965) and Davidoff et al. (2005)) and the low annuity takeup that is empirically observed (Benartzi et al., 2011).
} 
The most likely reason why annuitants are less informed about their payout choice is that the annuity is the default option or the 'path of least resistance,' using the terminology of Choi et al. (2002). Individuals often stick with the default because they tend to delay decisions longer than they should and because acts of commission, such as opting out of default, often come with significant transaction costs (Choi et al., 2003). In our case, individuals may also have refrained from making an active choice because they procrastinated until it was too late to collect the relevant information to make an informed choice, or because they did not trust their own judgement in making the right choice. Some may even have missed the opportunity of making a payout choice altogether. In fact, one of the few characteristics that predict ignorance is working after retirement. Working pensioners, who may have a lower propensity to think seriously about retirement-related issues, are (i) less likely to opt out of the default and (ii) less likely to remember their payout decision. ${ }^{5}$

The survey also asked participants whether they felt confident that they made the right payout choice. Previous evidence on the relationship between regret and payout decisions predicts an ambiguous relationship between annuitization and regret in our setting. On the one hand, Brown et al. (2011) show that individuals who were nudged into a specific retirement plan were more likely to regret their decision. On the other hand, people who buy annuities tend to be happier with their decision afterwards (Mitchell et al., 2003). I find that annuitants are, on average, significantly less confident that they made the right payout decision. Interestingly, this relationship becomes weaker when individuals who do not recall their payout decisions are included in the sample. ${ }^{6}$ This result suggests that strong nudges, such as default options, may reduce the level of ex-post regret among the less informed, or less engaged, individuals.

The survey is also used to study individual determinants and motives of annuitization. The survey participants were asked to report the importance of various factors with regard to their payout decisions. In addition, non-annuitants were asked to state their main reason for choosing a fixed-term payout. I restrict these analyses to individuals who accurately recalled their payout decisions in order to focus on annuitization that is likely an outcome of a conscious choice between payout options. ${ }^{7}$

Several individual characteristics are significantly correlated with payout choice. First, individuals with a large amount of pension wealth are more likely to annuitize. These individuals may have lower discount rates, incentives to choose a smaller monthly payout for tax reasons, sufficient money to participate in the annuity market in the first place, and more income to withstand unexpected health shocks (and can therefore afford to buy an annuity) (Bütler and Teppa, 2007; Inkmann et al., 2011; Hagen, 2015; Reichling and Smetters, 2015). ${ }^{8}$ Second, and as mentioned above, working pensioners are more likely to annuitize, as they may think less about payout-related issues and the pension-claiming process, and hence become more likely to stick with the default. Working individuals may also refrain from fixed-term payouts to avoid a higher marginal tax rate. Third, and in line with previous evidence of adverse selection in annuity markets (Finkelstein and Poterba, 2002, 2004), annuitization is increasing in self-reported health. Finally, individuals who consulted a financial advisor prior to the claiming decision are significantly less likely to annuitize. This

\footnotetext{
${ }^{5}$ In general, the low recollection rate observed in this setting reflects a significant body of evidence from many different countries, including Sweden, that pension plans tend to be characterized by low engagement and various behavioral biases such as inattention, status quo bias, and procrastination. There is ample evidence of investor mistakes and inertia in individual pension accounts (Cronqvist and Thaler, 2004; Palme et al., 2007; Dahlquist and Martinez, 2015; Cronqvist et al., 2018; Böhnke et al., 2019). Decisions that are made close to retirement have also been shown to be affected by various behavioral biases (Thaler, 1985; Bütler and Teppa, 2007; Brown et al., 2008; Bockweg et al., 2018). In a recent study, Hagen et al. (2018) show that small modifications in the pension application form had substantial impact on individuals' annuitization decisions.

${ }^{6}$ The interviewers used the information on actual payout decisions to inform mistaken survey participants about their true payout decisions before moving on to the series of questions on their reasons for choosing whether or not to annuitize. Therefore, when they answered the 'regret' question, they had their actual payout decision in mind.

${ }^{7}$ As a robustness test, alternative sample definitions are applied, including (i) only those who needed a reminder to accurately recall their payout decision, and (ii) all survey participants.

${ }^{8}$ That tax incentives matter for annuitization decisions have been shown by Bütler and Ramsden (2017); Hagen (2015), and Lee (2016). Two related studies, Bütler et al. (2013) and Chalmers and Reuter (2012), have shown that annuity demand is affected by the price of the annuity.
} 
correlation could be because either active investors (who are more likely to opt out of the default) are also more likely to seek professional financial advice or financial advisors recommend individuals to take a fixed-term payout and invest the money elsewhere.

The most frequent self-reported reason for choosing a fixed-term payout is consumption flexibility. More than $40 \%$ of the answers cite the opportunity provided by fixed-term payouts to spend more in the early years of retirement. This result is in line with the empirical fact that real household consumption declines gradually during retirement (Hurd and Rohwedder, 2011). It also suggests that allowing for partial annuitization may increase the average percentage of pension wealth being annuitized (Beshears et al., 2014).

The second most frequent self-reported reason for choosing a fixed-term payout relates to a willingness to 'cash out the money before dying." In line with theories of loss aversion, individuals may avoid annuitization because they place more weight on the potential losses in the case of an early death than the equivalent gains in the case of longer life (Hu and Scott, 2007). The so-called insurance fallacy - individuals do not insure themselves against good events, such as living longer - may also play a role here (Goedde-Menke et al., 2014).

The remainder of this paper is organized as follows. Section 2 provides a brief description of the Swedish pension system, with emphasis on the structure of the occupational pension plan for whitecollar workers. Section 3 describes the survey design, and Section 4 presents and discusses the empirical results. Section 5 presents additional tests, including separate analyses of the various fixed term-payouts, and robustness checks. Section 6 concludes.

\section{Institutional background}

\subsection{The structure of the Swedish pension system}

Sweden's pension system has two main pillars: a universal public pension system and a quasimandatory occupational pension system for workers whose employer is tied to some occupational pension plan. ${ }^{10}$ Mandatory annuitization applies to all pension wealth in the public pension system. The public pension can be withdrawn at age $61 .{ }^{11}$ While there is no legislated normal retirement age, workers are obliged to leave their employment at age 67 if requested by the employer to do so. ${ }^{12}$

The second pillar consists of several different occupational, employer-provided pension plans. Most occupational pension plans are designed and implemented at the union level. There are four large agreement-based occupational pension plans that cover at least $90 \%$ of the total work force (Kjellberg, 2018). Two of these plans cover workers employed in the public sector. The other two pension plans cover white-collar workers and blue-collar workers in the private sector, respectively. This study focuses on payout choices in Industrins och handelns tilläggspension (ITP), the pension plan for white-collar workers in the private sector.

\subsection{The occupational pension for white-collar workers}

The most important source of occupational pension income for white-collar workers in the ITP plan is DB. This component, which is referred to as ITP2, is the focus of this study.

Benefits from ITP2 depend on the final wage prior to retirement. The basic replacement rate of ITP2 is $10 \%$ of the final wage. This rate applies to earnings below the so-called income ceiling in

\footnotetext{
${ }^{9}$ Although this category might capture some individuals with low life expectancy, only about $7 \%$ specifically mentioned their poor health or low life expectancy as the main reason for choosing a fixed-term payout.

${ }^{10}$ There is also a third pillar for voluntary savings available to anyone who wishes to supplement the retirement income provided by the first two pillars. Up until 2016, there were tax incentives to save in particular pension funds; these have since been abolished.

${ }^{11}$ The minimum claiming age in the public pension was raised to 62 in 2020.

${ }^{12}$ The public pension system has three tiers, of which two are earnings-related and DC pensions. The third tier - the minimum guarantee pension - is paid out to retirees who have little or no earnings-related pension.
} 
the public pension system. ${ }^{13}$ The replacement rate for the portion of the final wage that exceeds the income ceiling is $65 \% .{ }^{14}$ The $65 \%$ corresponds to the targeted replacement rate for an average worker in the public pension system. The ITP plan, therefore, provides a top-up to the public pension below the income ceiling while maintaining the general replacement rate of about two-thirds of earnings above the income ceiling. This structure implies that the ITP plan plays a relatively more important role for high-income earners. ${ }^{15}$

Like many DB plans, ITP2 leaves little room for individual retirement savers to make their own decisions regarding their pensions. Individuals cannot decide on the magnitude of their own contributions (the replacement rates described above are fixed and apply to everyone); neither are they offered any investment choice during the accumulation phase. ITP2 wealth cannot be transferred from the default managing company, Alecta, to another pension company.

As for the decumulation phase, pensions from ITP2 can be withdrawn from the age of 55, and there is no upper age limit for initiating the payment. If no action is taken by the retiree, the pension is paid out as a life annuity at age 65 . While mandatory annuitization used to apply to all ITP2 benefits, fixedterm payouts were introduced as an alternative to annuitization in $2008 .^{16}$ The details surrounding the payout choice are described in the next section.

\subsection{Payout options}

White-collar workers receive an information letter about the available payout options from Alecta, 3 months before their 65th birthday, along with the corresponding monthly amounts. Individuals can choose to withdraw their ITP2 pension either as a life annuity or over a fixed number of years $\left(5,10,15\right.$, or 20 years). ${ }^{17}$ The life annuity guarantees the retiree a stream of money up until the point of death. Under fixed-term payouts, payments cease at the end of the stipulated term, or if the individual dies before the end of the term. There is no survivor benefit, meaning that any remaining pension wealth accrues to the other participants of the pension plan. Payments from ITP2 are adjusted for inflation. As noted above, the default is a life annuity paid out at the age of 65 .

The conversion factors that determine the relationship between the payout options depend on assumptions about average life expectancy at each claiming age and the rate of return on the pension capital. The conversion factors are, however, independent of gender and marital status. In 2013, the year in which the payout decisions under study were made, the conversion factors at age 65 between the life annuity and the 5-, 10-, 15-, and 20-year payouts were 3.73, 2.72, 1.46, and 1.21, respectively. For example, if an individual is entitled to a life annuity of SEK 2,500 per month, he or she can instead choose a 5-year option paying SEK 9,325 $(3.73 \times 2,500)$, a 10 -year option paying SEK 6,800 $(2.72 \times$ $2,500)$, a 15 -year option paying SEK $3,650(1.46 \times 2,500)$, or a 20 -year option paying SEK 3,025

\footnotetext{
${ }^{13}$ The income ceiling is indexed to the average income level in Sweden through the so-called income base amount (IBA). The ceiling is set at 7.5 IBA, which in 2013 corresponded to a monthly pre-tax income of SEK 35,375.

${ }^{14}$ Specifically, the ITP2 benefit is calculated according to the following equation, where $w_{i}$ denotes the wage portion related to the IBA $i$ :

$$
\mathrm{ITP} 2=0.1 w_{<7.5 \mathrm{IBA}}+0.65 w_{7.5-20 \mathrm{IBA}}+0.325 w_{20-30 \mathrm{IBA}}
$$

For full ITP2, 30 whole entitlement years are required. An entitlement year can be earned from age 28.

${ }^{15}$ Approximately one-fifth of the white-collar workers who retired at age 65 in 2013 had earnings above the income ceiling in the years prior to retirement.

${ }^{16}$ The ITP plan was reformed in 2006 when ITP2 was replaced by a new DC component called ITP1. Because this plan affects workers born in 1979 or later, it is not relevant to this study. The ongoing transition from DB to DC is part of an overall shift in pension provision among all major occupational pension plans in Sweden. For a more detailed description of the Swedish pension system, see Hagen $(2013,2017 a)$.

${ }^{17}$ In practice, retirees are allowed to withdraw their pensions over any period of time with the minimum being a 5 -year period. However, only $1 \%$ choose a payout length that is neither the pre-specified fixed-term payout lengths $(5,10,15$, and 20 years) nor the life annuity (Hagen, 2015).
} 
$(1.21 \times 2,500)$. Fixed-term payouts, therefore, increase liquidity but remove the insurance against upside longevity.

Hagen (2015) compares the expected discounted present value of the life annuity to the expected discounted present value of each of the fixed-term payouts in ITP2. ${ }^{18} \mathrm{He}$ finds a ratio marginally below one for all payouts, meaning that the average worker is expected to receive at least as much from a fixed-term payout compared to the life annuity over the remaining expected lifetime. Hagen (2015) also shows that the attractiveness of the life annuity increases if we consider the expected value of different payout options net of taxes. Due to the progressivity of the tax schedule, the average tax rate on the pension income from ITP2 decreases with the length of the payout for a given level of non-ITP2 income. ${ }^{19}$ In other words, shorter payment horizons result in higher monthly income, but also higher tax bills.

Individuals may receive occupational pension income from different occupational pension plans, and hence they are required to make more than one payout decision. Importantly, the other major occupational pension plans allow only DC capital to be withdrawn as fixed-term payouts. For today's elderly, the pension capital that is not subject to mandatory annuitization in these plans is therefore generally much smaller than that in ITP2 because individuals started to accumulate DC capital in these plans only in the late 1990s or early 2000s. In fact, ITP2 is the only DB plan in Sweden to allow fixed-term payouts. Pension income from the public pension system and other occupational pension plans that the survey participants may have contributed to during their working career can therefore be thought of as pre-annuitized wealth. ${ }^{20}$

\section{The survey}

I designed the survey together with the pension company Alecta, which manages ITP2 pensions for Swedish white-collar workers. We hired the survey firm Ipsos $^{21}$ to administer the survey by telephone in early 2014. The population of interest consisted of 28,000 white-collar workers who had started to withdraw their occupational pension from Alecta in 2013 when they turned 65, which is the normal retirement age. Focusing on withdrawals that were initiated at age 65 is not a major restriction; in 2013, as many as $86 \%$ started to collect their ITP2 pension at this age. At the time of the interview, the majority of participants were 65 years old while some had just turned 66 .

The pre-determined number of interviewed individuals was 1,000 . The sample was stratified on payout choice such that $60 \%$ of the interviewed individuals would have chosen a fixed-term payout $\left(5,10,15\right.$, or 20 years) and the remaining $40 \%$ the life annuity. ${ }^{22}$ The upper panel of Table 1 , which compares the distribution of payout choices in the sample population to that of the population of interest, shows that the stratification strategy worked. Close to $40 \%$ of the survey participants chose the life annuity while the corresponding fraction in the population of interest amounted to $75 \%$. Individuals were chosen randomly within each group until the pre-determined quota was met.

Around 900 individuals who were contacted declined to participate in the survey. The proportion of annuitants among those who refused to participate is very similar to the targeted share of

\footnotetext{
${ }^{18}$ The ratio of the expected discounted present value of the life annuity to that of an alternative payout is referred to as the money's worth ratio (MWR) of the life annuity. The MWR is a traditional measure of an annuity's value, and has been used in a number of earlier studies including Friedman and Warshawsky (1988); Mitchell et al. (1999); Brown and Poterba (2000); Finkelstein and Poterba (2004), and Chalmers and Reuter (2012).

${ }^{19}$ Retirement income from public and private pension plans are subject to the same tax rules as income from labor. A proportional local tax rate applies to all earned income and taxable transfers including pension income. For incomes above a certain threshold, the taxpayer also has to pay an additional state marginal tax of $20 \%$. Hagen (2015) shows that the average tax rate on the pension could increase by almost $40 \%$ if an individual reaches this threshold under the 5 -year payout. Around $10 \%$ of the population of interest pay the additional state marginal tax at age 66 .

${ }^{20}$ The data used in this paper do not have information on annuity choices in other pension plans.

${ }^{21}$ https://www.ipsos.com/sv-se

${ }^{22}$ The reason for stratifying on payout choice is that Alecta was particularly interested in learning more about the reasons why people choose not to annuitize their pension wealth.
} 
Table 1. Response analysis

\begin{tabular}{lcc}
\hline & Survey data & Register data \\
\hline Payout choice (stratified) & & \\
Life annuity & $39.3 \%$ & $74.7 \%$ \\
5-year payout & $32.7 \%$ & $15.2 \%$ \\
10-year payout & $18.3 \%$ & $6.8 \%$ \\
15-year payout & $8.8 \%$ & $3.1 \%$ \\
20-year payout & $0.9 \%$ & $0.2 \%$ \\
Demographics & & \\
Female & $42.2 \%$ & $41.6 \%$ \\
Pre-retirement income (SEK/month) & 22,240 & 23,140 \\
ITP2 annuity payment (SEK/month) & 2,510 & 2,970 \\
Elementary school & $16.3 \%$ & $16.8 \%$ \\
High school & $42.4 \%$ & $56.1 \%$ \\
College & $39.6 \%$ & $25.8 \%$ \\
PhD & $1.0 \%$ & $0.9 \%$ \\
\hline
\end{tabular}

This table reports individual characteristics and payout choices of the survey participants as well as the population of white-collar workers from which the survey sample was drawn. The sample was stratified on payout choice such that $60 \%$ of the interviewed individuals would have chosen a fixed-term payout $(5,10,15$, or 20 years) and the remaining $40 \%$ the life annuity. Income variables are in 2013 prices, US $\$ 1 \approx$ SEK 9 .

annuitants (i.e., 40\%). However, among the fixed-term payouts, having a 5-year payout is relatively less common in the survey ( $54 \%$ of the fixed-term payouts) than in the sample population $(60 \%$ of the fixed-term payouts). Correspondingly, fixed-term payouts of 10, 15, and 20 years are somewhat overrepresented in the sample population compared to the population of interest. In both populations, however, the demand for fixed-term payouts is negatively correlated to payment horizon with $<1 \%$ of those opting for a fixed-term payout choosing the 20-year payout.

To examine potential selection issues, we compare the characteristics of the survey participants with the characteristics of the population of interest. The lower panel of Table 1 reports the mean of several variables that can be observed for both populations. Reassuringly, we see that individuals in the survey sample are very similar to the population of interest in terms of gender, pre-retirement income, and education. Note, however, that the average ITP2 pension payment under the life annuity is somewhat smaller than the corresponding payment in the population of interest. ${ }^{23}$

The survey comprised 55 questions and the average completion time was 40 minutes. The survey participants were first asked to report which payout option they had chosen for their ITP2 pension. If they were unsure, or reported the wrong choice, the interviewer informed them of their actual choice. Then followed a series of questions related to their motivations for payout choice, demographics, current financial situation, time preferences, and financial literacy; these questions are described in more detail in the next section. The survey answers were then matched with Alecta's administrative data on the participants' actual payout choices.

\subsection{Survey questions and summary statistics}

The subsequent analysis of annuity demand will focus on the variables listed in Table 2. The first two columns present the mean and standard deviation of these variables, respectively. The third column provides the number of individuals who responded to the question, i.e., those who neither failed to answer the question nor answered 'do not know' or 'do not want to answer.' Note that only the register-based variables (pension size and gender) have 1,000 observations while the survey-based variables have fewer than 1,000 observations, in particular the question on preretirement income.

\footnotetext{
${ }^{23}$ The monetary value of the life annuity is calculated as the quota of the given benefit and the relevant conversion factor. For example, if the monthly benefit under the 5-year payout is SEK 2,500 and the (hypothetical) conversion factor is 3.73, the value of the life annuity is equal to SEK $714.3(2,500 / 3.73=670.2)$.
} 
Table 2. Participant characteristics

\begin{tabular}{|c|c|c|c|}
\hline & Mean & SD & Obs \\
\hline Female & 0.42 & 0.49 & 1,000 \\
\hline Married & 0.78 & 0.42 & 997 \\
\hline Number of children & 1.99 & 1.16 & 979 \\
\hline Retired & 0.63 & 0.48 & 997 \\
\hline Work 1 day or less per week & 0.15 & 0.36 & 997 \\
\hline Work several days or more per week & 0.22 & 0.41 & 997 \\
\hline On sick leave prior to retirement & 0.11 & 0.32 & 993 \\
\hline Pre-retirement after-tax income (SEK/month) & 22,243 & 11,405 & 879 \\
\hline ITP pension under annuity (SEK/month) & 2,507 & 3,972 & 1,000 \\
\hline Homeowner & 0.85 & 0.36 & 996 \\
\hline \multicolumn{4}{|l|}{ Highest education attained } \\
\hline Elementary school & 0.16 & 0.37 & 994 \\
\hline High school & 0.42 & 0.49 & 994 \\
\hline College (or higher) & 0.41 & 0.49 & 994 \\
\hline Financially literate (3 out of 3 ) & 0.52 & 0.50 & 1,000 \\
\hline Talked to financial advisor & 0.36 & 0.52 & 1,000 \\
\hline Self-reported health (1-10) & 7.98 & 2.01 & 993 \\
\hline Do not think about future $(1-10)$ & 5.41 & 2.94 & 995 \\
\hline Likes taking risks $(1-10)$ & 2.93 & 2.28 & 996 \\
\hline Trust in pension providers $(1-10)$ & 7.12 & 2.59 & 1,000 \\
\hline Frequent trader $(1-10)$ & 3.11 & 2.80 & 997 \\
\hline \multicolumn{4}{|l|}{ Factor ratings $(1-10)$} \\
\hline Tax reasons & 3.05 & 2.80 & 969 \\
\hline In need of money at retirement & 3.24 & 3.10 & 983 \\
\hline Important that pension secures old-age consumption & 8.44 & 2.35 & 989 \\
\hline Invest money on my own & 4.65 & 3.32 & 973 \\
\hline Leave an inheritance & 4.31 & 2.93 & 989 \\
\hline Want to cash out money before I die & 8.28 & 2.54 & 993 \\
\hline There was a recommended payout option that I chose & 4.73 & 3.49 & 937 \\
\hline
\end{tabular}

This table reports summary statistics for the survey sample. Income variables are in 2013 prices, US $\$ 1 \approx$ SEK 9.. The variables are described in Section 3.1.

The first set of questions reported in Table 2 relate to individual background characteristics: 58\% of the survey participants are male; $78 \%$ are married; and the average number of children is close to 2. Also, 63\% report that they are retired (not working at all), and about one-fifth work several days per week or more. The average net-of-tax income before retirement is approximately SEK 22,200 (US $\$ 1 \approx$ SEK 9), which is $10 \%$ higher than the national average in the age group 60-64 years.

The average monthly pension from ITP2 is SEK 4,445 (SEK 2,500 under the life annuity), which is approximately $20 \%$ of the average self-reported (pre-tax) income at age $66 .{ }^{24}$ When asked about the relative importance of the ITP2 pension for their total retirement income, $13 \%$ report that more than $50 \%$ of their total retirement income comes from this pension plan, $22 \%$ report between $30 \%$ and $50 \%$, $31 \%$ between $10 \%$ and $30 \%, 13 \%$ below $10 \%$ while $21 \%$ do not know (not reported in the table). Thus, the ITP2 pension clearly makes up a sizable part of total retirement income.

Turning to education, $16 \%$ finished only elementary school and around $41 \%$ have a college degree. The corresponding shares in the general population of 65-year-olds in Sweden amount to approximately $25 \%$ and $30 \%$, respectively. We conclude that our group of white-collar workers are on average better off both in terms of income and education than other Swedes of similar age.

In line with this finding, I also find that survey respondents have a relatively high level of financial literacy. Specifically, slightly more than half of the survey participants responded correctly to three standard questions on financial literacy, called the 'Big Three' (Lusardi and Mitchell, 2014). ${ }^{25}$ This

\footnotetext{
${ }^{24}$ This finding is in line with the register-based information on the population of interest. At age 66, one year after claiming their pensions, close to $20 \%$ of total retirement income comes from the ITP plan.

${ }^{25}$ These questions concern compounding, inflation, and diversification and comprise: Interest compounding: Suppose you have SEK 100 in a savings account with a $2 \%$ yearly interest rate. How much would you have in the account after 5 years if
} 
share is much higher than in Almenberg and Säve-Söderbergh (2011) and Almenberg et al. (2020) who asked similar questions to a representative sample of the Swedish working-age population in 2011 and 2014, respectively. Moreover, about one-third of the survey participants said they had consulted with a financial advisor prior to making their payout decision.

Participants were also asked to rank the extent to which they agreed with the following statements on a scale from 1 to 10 (a higher number means that they agree more): 'I do not think much about my future needs'; 'I like taking risks to win big'; 'I trust the pension companies that manage my pension wealth'; and 'I often make changes in my financial portfolio.' They were also asked to rank the following two statements related to present-bias and risk tolerance, respectively: 'I do not think much about what I need in the future'; and 'I am a person who likes taking risks to win big in the future.'

Finally, participants were asked to rate the importance on a scale from 1 to 10 ( 1 for not important, 10 for very important) of seven statements related to their payout choice. These include: 'There were tax reasons behind my payout choice'; 'I was in great need of money when I claimed my occupational pension'; 'I want to invest my pension capital on my own'; 'I want to leave a sizable inheritance'; 'I want to cash out as much as possible of the pension before I die'; and 'there was a recommended payout option that I chose.' We will henceforth refer to these as 'factor ratings.'

\section{Main results}

This section presents three sets of results: recollection of payout decision (4.1), demographic correlates of annuitization (4.2), and factor ratings (4.3). Section 5 provides robustness checks and additional analyses of payout demand, including separate analyses of the different fixed-term payouts and the relationship between regret and payout decisions. All estimations with a binary outcome are performed using linear probability models with robust standard errors. ${ }^{26}$ In the estimations, I also apply inverse probability weighting to account for the oversampling of fixed-term payouts vis-à-vis the life annuity and the overrepresentation of longer fixed-term payouts, i.e., $>5$ years (see Section 3 ). ${ }^{27}$

\subsection{Recollection of payout decision}

The first annuity-related question in the survey asked participants whether their ITP2 pension would be paid out 'as a lifelong payment' or 'during a fixed number of years.' If participants were unsure, or reported the wrong choice, the interviewer informed them of their actual choice. The upper panel of Table 3 reports the share who reported having chosen the life annuity (column 1); having chosen any of the fixed-term payouts (column 2); or not knowing or recollecting (column 3) for annuitants (row 1) and non-annuitants (row 2), respectively. The last column shows that 946 out of 1,000 individuals responded to this question.

We first see that only $40 \%$ of the annuitants correctly reported having chosen the life annuity. About one-third thought they had chosen a fixed-term payout while $26.9 \%$ said that they did not know. $^{28}$ The share of correct answers among those who opted for a fixed-term payout is almost twice that of the annuitants (76.9\%). Among those who chose a fixed-term payout, only $10.7 \%$ incorrectly stated the life annuity as their choice while $12.4 \%$ were unsure. Although a higher share of

you left the money to grow? Answer choices: 'More than SEK 102'; 'Exactly SEK 102'; 'Less than SEK 102'; and 'Do not know.' Inflation: Suppose that the interest rate on your savings account is $1 \%$ and inflation is $2 \%$. If you let your money be for 1 year, would you be able to buy more, as much, or less for the money at the end of the year? Answer choices: 'More'; 'As much'; 'Less'; 'Do not know.' Diversification: Is the following statement true or false? Buying stocks in a single company is generally safer than buying shares in a stock mutual fund. Answer choices: 'True'; 'False'; 'Do not know.'

${ }^{26}$ The exception is the analysis in Section 5.2 where I differentiate between the different fixed-term payouts (i.e., 5-, 10-, $15-$, and 20-year payouts). A multinominal logit model is applied for this purpose.

${ }^{27}$ Specifically, the weight, $\omega$, for payout option $j$ is calculated as $\omega_{j}=S_{j, \text { pop }} / S_{j, \text { survey, where }} S_{j, \text { pop }}$ and $S_{j, \text { survey }}$ is the share choosing payout option $j$ in the population of interest and in the survey population, respectively.

${ }^{28}$ Close to $80 \%$ of the annuitants who (falsely) believed they had chosen a fixed-term payout said - in a follow-up question- that they had a 5-year payout; one-fifth stated the 10-year payout while only a few a payout of 15 or 20 years. 
Table 3. Knowledge of payout decision

\begin{tabular}{|c|c|c|c|c|}
\hline & Life annuity (\%) & Fixed-term payout (\%) & Don't know (\%) & Obs \\
\hline \multicolumn{5}{|l|}{ Initial answer } \\
\hline Has life annuity & 40.0 & 33.1 & 26.9 & 375 \\
\hline Has fixed-term payout & 10.7 & 76.9 & 12.4 & 571 \\
\hline \multicolumn{5}{|l|}{ Answer after correction } \\
\hline Has life annuity & 55.6 & 8.0 & 36.4 & 225 \\
\hline Has fixed-term payout & 6.8 & 66.9 & 26.3 & 133 \\
\hline
\end{tabular}

This table reports the share of the survey sample who reported having chosen a life annuity (column 1); having chosen a fixed-term payout (column 2); or not knowing or recollecting (column 3) by their actual payout decision. The lower panel restricts the sample to those who initially stated the incorrect payout option or not knowing.

correct answers is expected among those who had chosen a fixed-term payout as they had rejected the default option, the difference is substantial.

The lower panel of Table 3 shows that the majority of participants who either got the payout option wrong or said that they did not know, agreed with the interviewer when they were informed of their true payout choice. A small proportion $(<10 \%)$ insisted on their initial response, and between $26 \%$ and $36 \%$ said that they still do not know.

To examine the characteristics of those who manage or fail to recall their true payout choice, Table 4 reports the results from regressing a dummy variable that takes on the value of 1 if the individual reports the correct payout choice on (most of) the variables listed in Section 3. I use dummy variables to rank individuals by pre-retirement income and ITP2 pension capital: 1st-10th percentile, 10th-30th percentile, 30th-70th percentile (omitted category), 70th-90th percentile, and 90th-100th percentile. The samples in column (1) and (2) comprise annuitants and non-annuitants, respectively. Note that the sample size is smaller than 946 (the number of individuals who reported a payout choice) because there are missing entries for most variables in the data (see Table 2).

Among annuitants, the only significant variable predicting whether they are able to accurately recall their payout choice is pension wealth; those in the top wealth decile are 24 percentage points more likely to report the correct pension choice compared to those in the middle (30th-70th percentile). Individuals in the bottom wealth quartile are also more likely to report the correct payout choice compared to those in the middle of the wealth distribution, but the coefficient is not statistically different from zero. Individuals with higher levels of income, the more highly-educated, and males are more likely to correctly report their payout choice; however, none of these coefficients is statistically significant. Turning to non-annuitants, individuals who consulted with a financial advisor prior to making their payout decision are almost 10 percentage points more likely to report the correct payout choice. The likelihood of answering correctly is also higher among more risk-averse individuals. ${ }^{29}$

To increase the sample size and potentially the precision of the estimates, I re-estimate Table 4 for a combined sample of annuitants and non-annuitants. The results are presented in Table A1 in the Appendix. While the overall picture does not change much, the coefficient associated with working at least several days per week (at age 66) becomes significant at the $5 \%$ level. The finding that individuals who continue to work past the normal retirement age have greater difficulty in recollecting their actual payout choice suggest that they thought less about their pension decisions. ${ }^{30}$ This interpretation is supported by the finding that the negative effect on remembrance is driven by annuitants, i.e., individuals who, either consciously or unconsciously, chose the default payout option.

\footnotetext{
${ }^{29}$ I also test for the overall significance of the capital and income rank variables, respectively. Only the $F$-test for the pension capital rank variables for annuitants in column (1) indicates joint significance (see table footnote).

${ }^{30}$ The survey also asked individuals to state how much effort they put into the payout decision. Indeed, there is a negative relationship between the amount of work after 65 and the amount of effort put into the payout decision (not reported).
} 
Table 4. Demographic correlates of correct belief

\begin{tabular}{|c|c|c|c|c|}
\hline \multirow[b]{3}{*}{ Female } & \multicolumn{2}{|c|}{ (1) } & \multicolumn{2}{|c|}{$(2)$} \\
\hline & \multicolumn{2}{|c|}{ Annuitants } & \multicolumn{2}{|c|}{ Non-annuitants } \\
\hline & -0.0714 & $(0.0694)$ & 0.0690 & $(0.0450)$ \\
\hline Married & -0.0448 & $(0.0765)$ & -0.00165 & $(0.0505)$ \\
\hline Number of children & 0.0158 & $(0.0248)$ & -0.000708 & $(0.0174)$ \\
\hline Work 1 day or less per week & -0.0226 & $(0.0820)$ & 0.0389 & $(0.0532)$ \\
\hline Work several days or more per week & -0.0904 & $(0.0685)$ & 0.00112 & $(0.0585)$ \\
\hline On sick leave prior to retirement & 0.0145 & $(0.0941)$ & -0.0122 & $(0.0659)$ \\
\hline Homeowner & -0.0433 & $(0.0862)$ & 0.0950 & $(0.0608)$ \\
\hline \multicolumn{5}{|l|}{ ITP pension capital rank } \\
\hline$<p 10$ & 0.165 & $(0.116)$ & -0.0356 & $(0.0607)$ \\
\hline p10-p30 & -0.0801 & $(0.0842)$ & -0.0226 & $(0.0514)$ \\
\hline p70-p90 & 0.0125 & $(0.0793)$ & 0.0558 & $(0.0568)$ \\
\hline$>$ p90 & $0.240^{\star *}$ & $(0.102)$ & 0.113 & $(0.0860)$ \\
\hline \multicolumn{5}{|l|}{ Pre-retirement income rank } \\
\hline$<p 10$ & -0.0631 & $(0.104)$ & -0.102 & $(0.0732)$ \\
\hline p10-p30 & 0.00458 & $(0.0828)$ & 0.0390 & $(0.0497)$ \\
\hline p70-p90 & 0.103 & $(0.0897)$ & -0.0360 & $(0.0628)$ \\
\hline$>\mathrm{p} 90$ & 0.0834 & $(0.112)$ & -0.0153 & $(0.102)$ \\
\hline \multicolumn{5}{|l|}{ Highest education attained } \\
\hline High school & 0.0432 & $(0.0868)$ & -0.0101 & $(0.0501)$ \\
\hline College (or higher) & 0.0775 & $(0.0877)$ & -0.0464 & $(0.0538)$ \\
\hline Financially literate ( 3 out of 3 ) & -0.0413 & $(0.0598)$ & 0.0475 & $(0.0389)$ \\
\hline Talked to financial advisor & -0.0808 & $(0.0508)$ & $0.0985^{\star \star}$ & $(0.0381)$ \\
\hline Self-reported health (1-10) & -0.00793 & $(0.0169)$ & -0.00770 & $(0.00924)$ \\
\hline Do not think about future $(1-10)$ & -0.0101 & $(0.00980)$ & -0.00514 & $(0.00658)$ \\
\hline Likes taking risks (1-10) & 0.0204 & $(0.0153)$ & $-0.0197^{\star \star}$ & $(0.00965)$ \\
\hline Trust in pension providers $(1-10)$ & 0.00898 & $(0.0111)$ & -0.000336 & $(0.00765)$ \\
\hline Frequent trader $(1-10)$ & -0.0107 & $(0.0124)$ & 0.00734 & $(0.00688)$ \\
\hline Constant & $0.471^{\star \star}$ & $(0.211)$ & $0.747^{\star \star \star}$ & $(0.136)$ \\
\hline Observations & 307 & & 493 & \\
\hline
\end{tabular}

* Significant at the $10 \%$ level. ${ }^{* \star}$ Significant at the $5 \%$ level. ${ }^{* \star \star}$ Significant at the $1 \%$ level.

The $p$-value from an overall F-test of the joint significance of the pension capital rank variables is 0.03 for annuitants (1) and 0.43 for non-annuitants (2). The corresponding p-value for the pre-retirement income rank variables is 0.71 for annuitants (1) and 0.99 for non-annuitants (2).

This table reports the coefficient estimates from a linear probability model regressing a dummy variable that takes on the value of 1 if the individual reports the correct payout choice on a set of independent variables. The samples in column (1) and (2) are restricted to annuitants and non-annuitants, respectively. Inverse sampling probabilities were used. Robust standard errors are in parentheses.

\subsection{Demographic correlates of annuitization}

In this section, I examine the demographic correlates of annuitization among our sample of whitecollar workers. I restrict the sample to individuals who knew their payout choice, i.e., $40 \%$ of annuitants and $77 \%$ of non-annuitants (see Section 4.1). The reason for this restriction is to focus on annuitization that was likely a deliberate and conscious decision. As a robustness test, alternative sample definitions are applied, adding, first, those who reported their actual payout choice after being reminded, and, second, the remaining survey participants.

The first column of Table 5 shows the results from regressing a dummy variable for choosing the life annuity on the variables listed in Table 2 (excluding the factor ratings). Out of the 946 individuals who reported a payout choice, 586 fulfil the restriction criteria above. The number of observations in Table 5 then falls to 506 because of missing information for some of the control variables. The corresponding estimates for the extended samples are presented in Table A2.

The results indicate that the monetary amount at stake in the annuity choice is an important predictor of payout decision. In fact, retirees in the top decile of pension capital are 28.3 percentage points more likely to annuitize than retirees in the middle of the pension capital distribution. The coefficients associated with the lower end of the pension capital distribution are negative but statistically insignificant. The corresponding estimates for the extended samples in Table A2 are, however, significant. 
Table 5. Demographic correlates of annuitization

(1)

\begin{tabular}{|c|c|c|}
\hline & \\
\hline & \multicolumn{2}{|c|}{ Life annuity } \\
\hline Female & $-0.103^{\star}$ & $(0.0595)$ \\
\hline Married & -0.0144 & $(0.0643)$ \\
\hline Number of children & 0.000571 & $(0.0207)$ \\
\hline Work 1 day or less per week & -0.0302 & $(0.0649)$ \\
\hline Work several days or more per week & 0.0578 & $(0.0575)$ \\
\hline On sick leave prior to retirement & -0.0139 & $(0.0893)$ \\
\hline Homeowner & -0.0499 & $(0.0686)$ \\
\hline \multicolumn{3}{|l|}{ ITP pension capital rank } \\
\hline$<p 10$ & -0.00475 & $(0.0890)$ \\
\hline p10-p30 & -0.104 & $(0.0788)$ \\
\hline p70-p90 & $0.126^{\star}$ & $(0.0705)$ \\
\hline$>$ p90 & $0.283^{\star \star *}$ & $(0.0684)$ \\
\hline \multicolumn{3}{|l|}{ Pre-retirement income rank } \\
\hline$<p 10$ & 0.0412 & $(0.0962)$ \\
\hline p10-p30 & 0.0101 & $(0.0734)$ \\
\hline p70-p90 & 0.0481 & $(0.0633)$ \\
\hline$>$ p90 & $0.138^{\star}$ & $(0.0772)$ \\
\hline \multicolumn{3}{|l|}{ Highest education attained } \\
\hline High school & $0.169 * *$ & $(0.0738)$ \\
\hline College (or higher) & $0.246^{\star \star \star}$ & $(0.0733)$ \\
\hline Financially literate ( 3 out of 3 ) & -0.0423 & $(0.0512)$ \\
\hline Talked to financial advisor & $-0.208^{\star \star \star}$ & $(0.0509)$ \\
\hline Self-reported health (1-10) & $0.0225^{\star}$ & $(0.0134)$ \\
\hline Do not think about future $(1-10)$ & 0.000274 & $(0.00834)$ \\
\hline Likes taking risks $(1-10)$ & $0.0224^{\star}$ & $(0.0117)$ \\
\hline Trust in pension providers $(1-10)$ & 0.0161 & $(0.0103)$ \\
\hline Frequent trader $(1-10)$ & $-0.0258^{\star \star \star}$ & $(0.00894)$ \\
\hline Constant & 0.225 & $(0.184)$ \\
\hline Observations & 506 & \\
\hline$R^{2}$ & 0.201 & \\
\hline
\end{tabular}

* Significant at the $10 \%$ level. ${ }^{\star \star}$ Significant at the $5 \%$ level. ${ }^{* \star \star}$ Significant at the $1 \%$ level.

The $p$-value from an overall $F$-test of the joint significance of the pension capital rank variables is $<0.00$. The corresponding $p$-value for the pre-retirement income rank variables is 0.50 .

This table reports the coefficient estimates from a linear probability model regressing a dummy variable that takes on the value of 1 if the individual chooses the life annuity on a set of independent variables. The sample is restricted to individuals who knew their payout choice. Inverse sampling probabilities were used. Robust standard errors are in parentheses.

Here, individuals in the lowest pension decile are 12.3 percentage points less likely to annuitize. These findings are in line with previous studies showing that small capital amounts tend to be withdrawn at a faster rate than larger amounts (Hurd and Panis, 2006; Bütler and Teppa, 2007; Hagen, 2015) perhaps because small amounts are discounted at higher rates than larger amounts (Frederick et al., 2002).

The relationship between annuitization and pre-retirement income is less clear. The only significant coefficient is for the top income decile; they are 13.8 percentage points more likely to annuitize than their peers at the 30th-70th percentiles of the pre-retirement income distribution. Hagen (2015) argues that individuals with the highest incomes may refrain from fixed-term payouts to avoid a higher marginal tax rate. ${ }^{31}$

The results also reveal that continuing to work after pension withdrawal is positively associated with annuitization. Individuals who work full-time or close to full-time are almost 6 percentage points more likely to annuitize compared to fully-retired individuals. The observed positive relationship could

\footnotetext{
${ }^{31}$ Importantly, this result is robust to excluding pension wealth from the regression. Given that ITP2 pensions are based on previous earnings, the two variables are highly correlated (the Pearson's correlation coefficient is 0.42). However, individuals with high earnings may have low pension wealth in the ITP plan if they spent substantial time working in other sectors with other pension plans. Likewise, individuals with low earnings prior to retirement may receive a large pension because they worked more hours at younger ages.
} 
possibly be explained by tax incentives or a lower propensity to think seriously about retirement-related issues (and hence to stick with the default payout option). The latter interpretation is supported by the finding in Section 4.1 that annuitants were less likely to recall their payout choice. This interpretation is also supported by the finding that the coefficient on working after retirement increases to 12 percentage points and becomes significant when the full sample is used (column (2) of Table A2).

The coefficients on education reflect an economically meaningful and statistically significant positive relationship between education level and annuitization. Having a college degree is associated with a 25-percentage-point higher likelihood of annuitizing compared to only having finished elementary school (12 percentage points for the full sample). We also see that women are less likely to annuitize, although this result is not robust to sample definition (see Table A2). A number of other demographic correlates, on the other hand, show no significant relationship with the annuity choice. Marital status, number of children, and homeownership are all close to zero and statistically insignificant.

It is also interesting to note that the coefficient for self-reported health is positive and significant. To the extent that subjective health is correlated with life expectancy, this result is in line with previous empirical studies on adverse selection in annuity markets (Finkelstein and Poterba, 2002, 2004; James et al., 2006). This result is also in accordance with Hagen (2015) who find that both ex-post mortality and parental longevity are significantly correlated with payout choice. Interestingly, the coefficient on self-reported health becomes insignificant when the sample is extended to those who needed a reminder of their payout choice in order to get it right. This result strengthens the interpretation that the detected positive relationship between self-reported health and annuitization is indeed driven by individuals who base their payout decision on their health status.

The statement related to present bias ('I do not think about the future') is not significantly correlated with the annuity choice. One reason why present-biased individuals are not more likely to annuitize might be that present-biased individuals are also more likely to procrastinate, and hence more likely to stick with the default option (Brown and Previtero, 2020).

When it comes to involvement in financial matters, individuals who report having consulted with a financial advisor or pension expert regarding their pension withdrawal are 20 percentage points less likely to annuitize ( 7 percentage points for the full sample). This decision could be because active investors are both more likely to opt out of the default and to seek professional financial advice. The decision could also be due to financial advisors prompting their clients to take a fixed-term payout and invest the money elsewhere. ${ }^{32}$ Finally, individuals who report that they often make changes to their financial portfolio are more likely to opt out of the life annuity.

\subsection{Factor ratings}

As discussed in Section 3.1, the survey participants were asked to report the importance of various factors with regards to their payout decision. Table 6, column (1), shows the results from regressing a dummy variable for choosing the life annuity on these factor ratings, conditional on the demographic variables discussed in the previous section. To examine whether certain groups of individuals placed more or less weight on certain factor ratings, column (2) adds interaction terms between each factor rating and a subset of the demographic variables used in (1). I focus on characteristics that turned out to be significantly correlated with annuity demand in Section 4.2, including continued work after claiming their pension, pension capital, pre-retirement income, education level, and consulting a financial advisor. ${ }^{33}$ Each factor rating is standardized to have a mean of zero and a variance

\footnotetext{
${ }^{32}$ Regressing a dummy for financial advice on the demographic correlates in Table 2 reveals that financial advice is significantly correlated with belonging to the top income decile and not working after claiming their pension.

${ }^{33} \mathrm{I}$ also examined the role of gender in this context. However, none of the gender-interacted factor ratings turned out to be significant and were thus excluded.
} 
Table 6. Factor ratings

\begin{tabular}{|c|c|c|c|c|}
\hline \multirow[b]{3}{*}{ Tax reasons } & \multicolumn{2}{|c|}{ (1) } & \multicolumn{2}{|c|}{ (2) } \\
\hline & \multicolumn{2}{|c|}{ Life annuity } & \multicolumn{2}{|c|}{ Life annuity } \\
\hline & -0.0257 & $(0.0232)$ & $-0.0829^{\star \star}$ & $(0.0410)$ \\
\hline Work several days or more per week & & & -0.0522 & $(0.0527)$ \\
\hline College (or higher) & & & $0.120^{\star \star}$ & $(0.0511)$ \\
\hline Above median pre-retirement income & & & 0.0483 & $(0.0685)$ \\
\hline Above median pension capital & & & 0.0190 & (0.0575) \\
\hline Talked to financial advisor & & & 0.00356 & $(0.0517)$ \\
\hline In need of money at retirement & $0.0518^{*}$ & $(0.0265)$ & $0.119^{\star \star \star}$ & $(0.0364)$ \\
\hline Work several days or more per week & & & $-0.0907^{\star}$ & $(0.0536)$ \\
\hline College (or higher) & & & -0.0267 & $(0.0552)$ \\
\hline Above median pre-retirement income & & & -0.0245 & $(0.132)$ \\
\hline Above median pension capital & & & -0.0822 & $(0.0677)$ \\
\hline Talked to financial advisor & & & $-0.125^{\star \star}$ & $(0.0548)$ \\
\hline Important that pension secures old-age consumption & $0.0605^{\star \star}$ & $(0.0276)$ & 0.0397 & $(0.0363)$ \\
\hline Work several days or more per week & & & $0.109^{*}$ & $(0.0648)$ \\
\hline College (or higher) & & & 0.0664 & $(0.0597)$ \\
\hline Above median pre-retirement income & & & -0.0990 & $(0.0750)$ \\
\hline Above median pension capital & & & 0.0878 & $(0.0646)$ \\
\hline Talked to financial advisor & & & -0.0607 & (0.0519) \\
\hline Invest money on my own & -0.0115 & $(0.0260)$ & 0.0163 & $(0.0406)$ \\
\hline Work several days or more per week & & & 0.0580 & $(0.0658)$ \\
\hline College (or higher) & & & -0.0434 & $(0.0586)$ \\
\hline Above median pre-retirement income & & & 0.0167 & $(0.0956)$ \\
\hline Above median pension capital & & & -0.00369 & $(0.0708)$ \\
\hline Talked to financial advisor & & & -0.0344 & $(0.0524)$ \\
\hline Leave an inheritance & -0.00894 & $(0.0248)$ & $-0.0631^{\star}$ & $(0.0380)$ \\
\hline Work several days or more per week & & & $0.148^{\star \star}$ & $(0.0596)$ \\
\hline college (or higher) & & & $-0.103^{*}$ & $(0.0599)$ \\
\hline Above median pre-retirement income & & & 0.00430 & $(0.128)$ \\
\hline Above median pension capital & & & 0.0557 & $(0.0673)$ \\
\hline Talked to financial advisor & & & $0.152^{\star \star \star}$ & $(0.0543)$ \\
\hline Want to cash out money before I die & $-0.0772^{\star \star *}$ & $(0.0214)$ & $-0.0863^{\star \star}$ & $(0.0341)$ \\
\hline Work several days or more per week & & & -0.0717 & (0.0539) \\
\hline College (or higher) & & & 0.0534 & $(0.0470)$ \\
\hline Above median pre-retirement income & & & 0.0427 & $(0.0901)$ \\
\hline Above median pension capital & & & -0.0231 & $(0.0556)$ \\
\hline Talked to financial advisor & & & -0.0363 & $(0.0584)$ \\
\hline There was a recommended payout option that I chose & $0.0787^{\star \star \star}$ & $(0.0231)$ & 0.0608 & $(0.0374)$ \\
\hline Work several days or more per week & & & -0.0522 & $(0.0552)$ \\
\hline College (or higher) & & & 0.00263 & (0.0509) \\
\hline Above median pre-retirement income & & & -0.105 & $(0.102)$ \\
\hline Above median pension capital & & & 0.104 & $(0.0745)$ \\
\hline Talked to financial advisor & & & 0.0493 & $(0.0516)$ \\
\hline Observations & 467 & & 467 & \\
\hline
\end{tabular}

* Significant at the $10 \%$ level. ** Significant at the $5 \%$ level. ${ }^{* \star *}$ Significant at the $1 \%$ level.

This table reports the coefficient estimates from a linear probability model regressing a dummy variable that takes on the value of 1 if the individual chooses the life annuity on participants' factor ratings. The factor ratings are standardized to have a mean of zero and a variance of one. Columns (1) and (2) control for the demographic variables in Table 5. Column (2) then adds interaction terms between each factor rating and a subset of the demographic variables used in (1). The sample is restricted to individuals who knew their payout choice. Inverse sampling probabilities were used. Robust standard errors are in parentheses.

of one. Recall that the sample is restricted to individuals who knew their payout choice. Tables A4 and A6 in the Appendix present corresponding estimates for the extended samples.

Four factor ratings are significant in the first column of Table 6. First, we see that annuitization is increasing in the importance placed on the factor 'I was in great need of money when I claimed my occupational pension.' The coefficients of the interaction terms in the second column show that this result is driven by retired individuals and individuals who did not seek financial advice. These individuals may have refrained from a higher pension payment today because they know that they are likely 
to also be cash-constrained in the future. ${ }^{34}$ Second, annuitization is increasing in the importance placed on the factor 'it is important that the pension covers my needs when I get very old.' This result is, again, driven by individuals who were active in the labor market after claiming their pension. In the robustness tables, we also see that individuals with large pension capital put more weight on this factor.

The third significant factor rating, which has a negative sign, is it is important for me to cash out as much as possible while I am still alive.' This statement could capture many things, such as low life expectancy, a desire to spend more in the early years of retirement, or a more general aversion to losing the money in the case of early death (irrespective of life expectancy). As argued later in Section 5.3, the two latter explanations are likely to matter more. No particular subgroup is uniquely associated with this factor rating as indicated by the insignificant interaction terms in the second column. Fourth, we see that some individuals chose life annuity because they interpreted the life annuity as the recommended option. The estimated coefficient for the statement 'there was a recommended payout option that I followed' is positive and significant. While none of the interaction terms is significant in Table 6, the coefficient for working several days a week or working full-time becomes negative and significant when I use the extended samples. These results support the interpretation that individuals who intend to work past the normal retirement age think less about payout-related issues and the pension-claiming process.

The second column of Table 6 contains two further findings that are worth pointing out. First, while the factor rating related to tax concerns ('There were tax reasons behind my payout choice.') is unrelated to the annuity choice in general (column 1), the estimate of the interaction term between the weight placed on the tax-related factor rating and having a college degree is positive and significant. In other words, individuals with a college degree, who on average have higher earnings than individuals without a college degree, may have chosen a life annuity, at least partly, for tax reasons. This finding is in line with Hagen (2015) who shows that individuals who may reach the state income tax threshold under a 5-year payout, thereby having to pay a larger share of their pension income in taxes, are less likely to choose the 5-year payout. Second, the interaction term between consulting a financial advisor and the factor rating related to bequest motives - 'I want to leave a sizable inheritance.' - is positive and significant. One interpretation of this result is that individuals who seek financial advice are less worried about their own financial security in old age because they have sufficient income from other sources (recall that they put less weight on the factor rating related to cash constraints); therefore, they put more time and thought into other factors that are important to them, such as leaving a sizable bequest.

\section{Further tests and robustness checks}

\subsection{Sampling reliability}

I perform several robustness checks to strengthen the internal validity of the results. As discussed in Section 4 , the results are overall relatively robust to sample specification (i.e., including individuals who did not know their payout choice).

As a further check on sampling reliability, I replace the survey data with register data, specifically individual-level demographic data from Statistics Sweden. I perform a similar analysis of the demographic correlates of annuity demand on the population of interest, i.e., the 28,000 white-collar workers who claimed their pension at age 65 in 2013. The Alecta dataset on pension payouts are merged with the Statistics Sweden dataset. ${ }^{35}$ While pension capital and gender are observed in both datasets, information on marital status, education level, employment at age 66, and pre-retirement income (average labor income between ages 60 and 64) are now drawn from Statistics Sweden instead of from the survey. The latter variables are defined in a way so that they mimic the (self-reported) equivalents in the survey. As a proxy for health, I include a dummy for having received disability pension.

\footnotetext{
${ }^{34}$ This interpretation gains additional support from the corresponding estimates using the extended samples in Tables A3 and A4. Including individuals who did not know their payout choice makes the interaction terms insignificant.

${ }^{35}$ See Hagen (2015) for a more detailed description of these datasets.
} 
Table 7. Demographic correlates of annuitization using register data

(1)

\begin{tabular}{|c|c|c|}
\hline & \multirow{2}{*}{\multicolumn{2}{|c|}{ Life annuity }} \\
\hline & & \\
\hline Female & 0.00197 & $(0.00551)$ \\
\hline Married & -0.00277 & $(0.00544)$ \\
\hline Employed & $0.0351^{\star \star \star}$ & $(0.00565)$ \\
\hline Disability pension & $-0.0219^{\star \star \star}$ & $(0.00828)$ \\
\hline \multicolumn{3}{|c|}{ Pre-retirement income rank } \\
\hline $\mathrm{p} 10$ & $0.0697^{\star \star \star}$ & $(0.00965)$ \\
\hline p10-p30 & $0.0251^{\star \star \star}$ & $(0.00773)$ \\
\hline p70-p90 & $0.0211^{\star \star \star}$ & $(0.00723)$ \\
\hline p90 & $0.0492^{\star \star \star}$ & $(0.0102)$ \\
\hline \multicolumn{3}{|c|}{ ITP pension capital rank } \\
\hline $\mathrm{p} 10$ & $-0.176^{\star \star \star}$ & $(0.00922)$ \\
\hline p10-p30 & $-0.0630^{\star \star \star}$ & $(0.00694)$ \\
\hline p70-p90 & $0.0280^{\star \star \star}$ & $(0.00724)$ \\
\hline p90 & $0.102^{\star \star \star}$ & $(0.0102)$ \\
\hline \multicolumn{3}{|c|}{ Highest education attained } \\
\hline High school & $0.0121^{\star}$ & $(0.00711)$ \\
\hline College (or higher) & $0.0398^{\star \star \star}$ & $(0.00765)$ \\
\hline Constant & $0.710^{\star \star \star}$ & $(0.00901)$ \\
\hline Observations & 27,425 & \\
\hline
\end{tabular}

* Significant at the $10 \%$ level. ** Significant at the $5 \%$ level. ${ }^{* \star}$ Significant at the $1 \%$ level.

This table reports the coefficient estimates from a linear probability model regressing a dummy variable that takes on the value of 1 if the individual chooses the life annuity on a set of independent variables. The regression sample contains the population of interest, i.e., white-collar workers who claimed their ITP2 pension at age 65 in 2013. The data are a combination of pension data from the managing company, Alecta, and individual-level demographic data from Statistics Sweden. The register-based variables are constructed to mimic the survey-based variables as closely as possible (see Section 5.1). Robust standard errors are in parentheses.

The estimation results from a linear probability model on annuity demand are shown in Table 7. Reassuringly, the results are largely in line with the findings in Table 5. While annuitization is unrelated to gender and marital status, it is increasing in education level, health status, and pension capital. Again, we see a U-shaped relationship between pre-retirement income and annuitization, although the $\mathrm{U}$ shape here is much more pronounced.

\subsection{Separating the fixed-term payouts}

Until now, we have grouped the fixed-term payouts in one category and focused on the demand for life annuities versus all fixed-term payouts. However, the motivations for choosing the 5-year payout may be very different from choosing, for example, the 10-year payout. For this reason, I use a multinomial logit model to study the relationship between the demand for each payout option and the demographic correlates and factor ratings. ${ }^{36}$

Using the life annuity as the reference category, columns (1)-(3) of Table 8 report marginal effects of each of the demographic correlates considered in Section 4.2 on the respective demand for these payout options: (i) 5 years; (ii) 10 years; and (iii) 15 or 20 years. The marginal effect of each of the binary variables is the discrete change from the base level while the non-binary variables are evaluated at their means.

We first see that the previously detected positive relationship between being female and the demand for fixed-term payouts is driven by demand for 5-year payouts. ${ }^{37}$ Potential reasons for this gender difference are discussed in Section 5.3.

\footnotetext{
${ }^{36}$ An ordinal model, such as ordered probit, may seem like a natural choice because of the stepwise increase in the length of the fixed-term payouts. However, the life annuity does not really follow along the same continuum because it - unlike the fixed-term payouts - insures against upside longevity. A multinomial logit model also allows individual characteristics to be different for different choices.

${ }^{37}$ That women have a stronger preference for 5-year payouts than men has also been observed in other occupational pension plans in Sweden (Hagen, 2015; ISF, 2015).
} 
Table 8. Demographic correlates of annuitization using a multinomial logit model (marginal effects)

\begin{tabular}{|c|c|c|c|c|c|c|}
\hline \multirow[b]{2}{*}{ Female } & \multicolumn{2}{|c|}{ 5-year } & \multicolumn{2}{|c|}{ 10-year } & \multicolumn{2}{|c|}{ 15/20-year } \\
\hline & $0.091^{*}$ & $(0.049)$ & 0.004 & $(0.042)$ & -0.039 & $(0.030)$ \\
\hline Married & -0.029 & $(0.053)$ & 0.046 & $(0.044)$ & -0.038 & $(0.042)$ \\
\hline Number of children & 0.003 & (0.019) & -0.017 & $(0.017)$ & 0.016 & $(0.012)$ \\
\hline Work 1 day or less per week & 0.012 & (0.058) & 0.016 & $(0.052)$ & -0.021 & $(0.035)$ \\
\hline Work several days or more per week & -0.064 & $(0.056)$ & -0.005 & $(0.050)$ & 0.006 & $(0.036)$ \\
\hline On sick leave prior to retirement & -0.083 & $(0.068)$ & $0.118^{*}$ & $(0.070)$ & -0.030 & $(0.043)$ \\
\hline Homeowner & 0.084 & $(0.060)$ & -0.054 & $(0.055)$ & 0.042 & $(0.039)$ \\
\hline \multicolumn{7}{|l|}{ ITP pension capital rank } \\
\hline$<p 10$ & $0.253^{\star \star \star}$ & $(0.066)$ & $-0.157^{\star \star \star}$ & $(0.042)$ & $-0.116^{\star \star \star}$ & $(0.014)$ \\
\hline p10-p30 & $0.105^{\star}$ & $(0.057)$ & 0.046 & $(0.048)$ & $-0.107^{\star \star \star}$ & $(0.022)$ \\
\hline p70-p90 & -0.006 & $(0.060)$ & $-0.155^{\star \star \star}$ & $(0.040)$ & 0.047 & $(0.038)$ \\
\hline$>p 90$ & $-0.294^{\star \star \star}$ & (0.066) & $-0.162^{\star \star \star}$ & $(0.048)$ & $0.120^{\star \star}$ & $(0.057)$ \\
\hline \multicolumn{7}{|l|}{ Pre-retirement income rank } \\
\hline$<p 10$ & -0.061 & $(0.072)$ & 0.004 & $(0.062)$ & 0.032 & $(0.069)$ \\
\hline p10-p30 & 0.045 & (0.056) & -0.051 & $(0.045)$ & -0.014 & $(0.039)$ \\
\hline p70-p90 & 0.001 & $(0.065)$ & -0.002 & $(0.058)$ & $-0.049^{*}$ & $(0.029)$ \\
\hline$>$ p90 & -0.134 & (0.096) & 0.079 & (0.094) & $-0.057^{\star}$ & $(0.033)$ \\
\hline \multicolumn{7}{|l|}{ Highest education attained } \\
\hline High school & -0.022 & $(0.055)$ & $-0.104^{\star \star}$ & $(0.044)$ & 0.008 & $(0.036)$ \\
\hline College (and higher) & -0.067 & (0.059) & $-0.110^{\star *}$ & $(0.045)$ & -0.008 & $(0.040)$ \\
\hline Financially literate ( 3 out of 3 ) & -0.024 & $(0.042)$ & -0.004 & $(0.037)$ & $0.063^{\star \star}$ & $(0.026)$ \\
\hline Talked to financial advisor & $0.126^{\star \star \star}$ & $(0.041)$ & 0.018 & $(0.036)$ & 0.001 & $(0.027)$ \\
\hline Self-reported health (1-10) & -0.014 & $(0.011)$ & 0.001 & $(0.010)$ & -0.005 & $(0.006)$ \\
\hline Do not think about future $(1-10)$ & -0.003 & $(0.007)$ & 0.003 & $(0.006)$ & -0.000 & $(0.005)$ \\
\hline Likes taking risks $(1-10)$ & 0.005 & (0.011) & -0.005 & $(0.009)$ & $-0.014^{\star \star}$ & $(0.006)$ \\
\hline Trust in pension providers $(1-10)$ & $-0.017^{\star \star}$ & (0.008) & 0.006 & $(0.007)$ & -0.001 & $(0.005)$ \\
\hline Frequent trader $(1-10)$ & $-0.016^{\star \star}$ & (0.008) & $0.019^{\star \star \star}$ & $(0.006)$ & $0.017^{\star \star \star}$ & $(0.005)$ \\
\hline Observations & 506 & & 506 & & 506 & \\
\hline
\end{tabular}

* Significant at the $10 \%$ level. ${ }^{\star *}$ Significant at the $5 \%$ level. ${ }^{\star \star \star}$ Significant at the $1 \%$ level.

This table reports marginal effects estimated using a multinomial logit model. The marginal effect associated with each coefficient can be interpreted as the variable's incremental effect on the probability of choosing the fixed-term payout indicated in the column heading. Note that 15- and 20-year payouts have been merged into one category. The life annuity is the reference category. The sample is restricted to individuals who knew their payout choice.

Moreover, we see that the previously insignificant correlation between sick leave and annuitization masks important heterogeneity with respect to the length of the fixed-term payouts. Specifically, individuals with a recent record of sick leave are almost 12 percentage points more likely to choose the 10 -year payout. In contrast, they are about 8 percentage points less likely to choose the 5 -year payout, although this estimate is statistically insignificant; this observation does not rule out the possibility that adverse selection plays a role in 5-year payouts since most people would expect to live longer than 10 years. Individuals in poor health may, however, be less concerned with maximizing consumption possibilities in the early years of retirement. The result with respect to health, combined with the observation that education is negatively related to the demand for 10-year payouts but not 5-year payouts, suggest that individuals at higher risk of ending up with an insufficient pension do not choose the payout that offers the most money now - the 5-year payout.

We also see important heterogeneity in the relationship between pension capital and the demand for the different fixed-term payouts. Recall from our main specification in Table 5 that while individuals with the largest capital stocks were significantly less likely to opt out of the life annuity, the corresponding relationship for individuals at the lower end of the capital distribution was inconclusive. The estimates in Table 8 help explain the latter finding: those with the smallest capital stocks clearly prefer 5-year payouts, but are less likely to choose a fixed-term payout of 10 years or longer.

Although the coefficients for pre-retirement income are insignificant, they reveal some differences with respect to income and payout preferences. While the demand for 5-year payouts is lower at both ends of the income distribution, the demand for 10 -year payouts seems to increase with income. We 
also see that the positive correlation between consulting a financial advisor and choosing a fixed-term payout is entirely driven by demand for 5 -year payouts.

Finally, there are two individual characteristics that were found to be unrelated to the annuity decision but are now revealed to have a significant correlation with a specific payout term. First, financial literacy is positively correlated with the probability of choosing the 15 - or 20 -year payout. Second, higher trust in pension providers reduces the likelihood of choosing the 5-year payout. Some individuals may prefer to cash out the money as fast as possible because they do not trust the pension provider to manage their money well or perhaps even to survive in the longer run. This result is in line with Brown et al. (2015) and Bockweg et al. (2018) who find that individuals who exhibit a lower level of confidence in the government or the pension system are substantially more likely to choose the more immediate payment option.

Turning to the factor ratings in Table 9, we see that the demand for 15 - and 20 -year payouts is lower for individuals who put more weight on the factor rating 'there was a recommended payout option that I chose.' Individuals who initially considered a fixed-term payout with a long payment horizon may have received some input during the claiming process about the advantages of insuring against upside longevity. We also see that a stronger preference for cashing out the money before dying is associated with a higher demand for 5-year payouts. The demand for 5-year payouts is also decreasing in the weight put on the statement it is important that the pension covers my needs when I get very old.'

\subsection{Self-reported reasons for choosing a fixed-term payout}

All non-annuitants who took part in the survey were asked to state the main reason for choosing a fixed-term payout. The text answers were then categorized into a number of reasons. Table 10 reports the distribution of 'self-reported reasons' for 5-year payouts (column 1), 10-year payouts (column 2), and 15 - or 20 -year payouts (column 3 ). ${ }^{38}$

More than one-third of those who chose the 5-year payout highlight the opportunity offered by fixed-term payouts to consume more during the early retirement years. This share is even higher among those who chose a fixed-term payout of 10 years or longer. The following statements are typical for the 'consumption flexibility' motivation: 'I need the money more now than I will later in life'; 'I have a more active life style today than I will have in 10-15 years'; and 'I want to enjoy the money as much as possible while I am still healthy.' Some individuals who reported having other occupational pensions said that choosing the fixed-term payout was part of a bigger 'pension puzzle.'

The second most common motivation relates to the idea of cashing out the money in the eventuality of an early death. 'You don't know when you are going to die' and 'I want to make sure I get the money before I die' are typical formulations in this category. This motivation is more frequently used by those who chose the 5 -year payout compared to others.

The poor health/low life expectancy category aims at capturing the adverse selection issue more specifically by including individuals who explicitly mentioned their poor health status or low life expectancy. Interestingly, this share is almost twice as large among individuals who chose the longer payouts compared to those who chose the 5-year payout. This finding is in line with the result from the multinomial logit analysis that individuals who were on sick leave prior to retirement were significantly more likely to choose the 10 -year payout than the 5-year payout.

We also see that around $9 \%$ take a fixed-term payout in order to invest the money on their own. Statements like 'I think I can earn a better return than the pension company' and 'I can use the money whenever I want by claiming the money quickly and saving it on my own' characterize this group. Between $5 \%$ and $15 \%$ report that they choose a fixed-term payout because the annuity would be too small. Only a few percent said that they chose a fixed-term payout to leave a bequest, or that

\footnotetext{
${ }^{38}$ The corresponding shares for the extended samples are shown in Table A7, and are overall quite similar to the main shares.
} 
Table 9. Factor ratings using a multinomial logit model (marginal effects)

\begin{tabular}{|c|c|c|c|}
\hline & 5-year & 10-year & 15/20-year \\
\hline \multirow[t]{2}{*}{ Tax reasons } & $\begin{array}{c}0.031 \\
0\end{array}$ & -0.011 & -0.002 \\
\hline & $(0.023)$ & $(0.021)$ & (0.014) \\
\hline \multirow[t]{2}{*}{ In need of money at retirement } & -0.028 & -0.013 & 0.014 \\
\hline & $(0.022)$ & $(0.020)$ & (0.015) \\
\hline \multirow[t]{2}{*}{ Important that pension secures old-age consumption } & $-0.051^{\star \star}$ & 0.008 & -0.013 \\
\hline & $(0.023)$ & $(0.021)$ & $(0.012)$ \\
\hline \multirow[t]{2}{*}{ Invest money on my own } & 0.037 & -0.032 & -0.007 \\
\hline & $(0.023)$ & $(0.021)$ & $(0.015)$ \\
\hline \multirow[t]{2}{*}{ Leave an inheritance } & 0.022 & 0.014 & -0.025 \\
\hline & $(0.021)$ & $(0.019)$ & $(0.015)$ \\
\hline \multirow[t]{2}{*}{ Want to cash out money before I die } & $0.066^{\star \star \star}$ & 0.008 & -0.003 \\
\hline & $(0.024)$ & $(0.021)$ & $(0.014)$ \\
\hline \multirow[t]{2}{*}{ There was a recommended payout option that I chose } & -0.014 & 0.010 & $-0.062^{\star \star \star}$ \\
\hline & $(0.022)$ & $(0.018)$ & $(0.017)$ \\
\hline Observations & 467 & 467 & 467 \\
\hline
\end{tabular}

* Significant at the $10 \%$ level. ${ }^{* \star}$ Significant at the $5 \%$ level. ${ }^{\star \star \star}$ Significant at the $1 \%$ level.

This table reports marginal effects estimated using a multinomial logit model. The marginal effect associated with each coefficient can be interpreted as the variable's incremental effect on the probability of choosing the fixed-term payout indicated in the column heading. Note that 15- and 20-year payouts have been merged into one category. The life annuity is the reference category. The sample is restricted to individuals who knew their payout choice.

Table 10. Self-reported reason for choosing a fixed-term payout

\begin{tabular}{lccr}
\hline & $(1)$ & $(2)$ & $(3)$ \\
& 5 years & 10 years & $15 / 20$ years \\
\hline Annuity too small & 14.7 & 10.7 & 5.2 \\
Invest money on my own & 8.7 & 8.4 & 10.3 \\
Consumption flexibility & 36.8 & 45.0 & 51.7 \\
Cash out money before I die & 23.4 & 13.7 & 17.2 \\
Bequest motives & 3.9 & 1.5 & 0.0 \\
Poor health/low life expectancy & 6.1 & 10.7 & 12.1 \\
Advised by friend or expert & 3.9 & 3.8 & 0.0 \\
No particular reason & 2.6 & 6.1 & 3.4 \\
Observations & 231 & 131 & 58 \\
\hline
\end{tabular}

This table reports the distribution (in \%) of the self-reported main reasons for choosing the fixed-term payout indicated in the column heading. Note that 15- and 20-year payouts have been merged into one category. The responses were categorized into the relevant groups by the author. The sample is restricted to individuals who knew their payout choice.

they were advised by an expert (or friend) to choose a fixed-term payout. Note, however, that these factors could matter alongside the main (stated) reason.

We know from previous sections that women are more likely to choose a 5-year payout than men. Women are, however, no more likely than men to know their payout choice, and none of the female-interacted factor ratings was significantly correlated with annuity demand. To gain some insight with respect to gender differences in payout motives, Table A6 reports the distribution of selfreported reasons by fixed-term payout and gender. ${ }^{39}$ From the top row, we see that a larger share of women report that they chose a fixed-term payout because the monthly payment under the life annuity was too small. This result is expected given that women on average have smaller pensions. Women are more likely than men to report that the main reason for choosing a 5-year payout is because they want to cash out the money before they die. This finding seems at odds with the fact that women tend to live longer than men, but could reflect differences in the availability of alternative sources of income

\footnotetext{
${ }^{39}$ Note that the number of observations for 15 - and 20 -year payouts becomes very small when the sample is split by gender.
} 
Table 11. Regret and annuitization

\begin{tabular}{|c|c|c|c|}
\hline & $\begin{array}{c}\text { (1) } \\
\text { Knew payout }\end{array}$ & $\begin{array}{c}(2) \\
\text { Knew/Needed reminder }\end{array}$ & $\begin{array}{l}\text { (3) } \\
\text { All }\end{array}$ \\
\hline No regret about payout decision & $\begin{array}{l}-0.0526^{\star \star} \\
(0.0245)\end{array}$ & $\begin{array}{r}-0.0329^{\star} \\
(0.0184)\end{array}$ & $\begin{array}{c}-0.0346^{\star \star} \\
(0.0147)\end{array}$ \\
\hline Observations & 487 & 643 & 794 \\
\hline
\end{tabular}

* Significant at the $10 \%$ level. ** Significant at the $5 \%$ level. ${ }^{* \star *}$ Significant at the $1 \%$ level.

This table reports the coefficient estimates from a linear probability model regressing a dummy variable that takes on the value of 1 if the individual chooses the life annuity on a set of independent variables, including the statement 'I am confident that I made the right choice of payout length' (answered on a scale from 1 to 10). The sample is restricted to individuals who knew their payout choice (column 1), individuals who knew their payout choice or needed a reminder to get it right (column 2), and all survey participants (column 3). Each regression controls for the demographic variables in Table 5. Inverse sampling probabilities were used. Robust standard errors are in parentheses.

(husband, family, first-pillar pension income). Finally, women are less likely than men to assert that they choose a 5 -year payout because they want to invest the money on their own. ${ }^{40}$

\subsection{Regret}

Section 4.1 provided evidence of widespread unawareness of past payout decisions, particularly among the annuitants (those who chose the default option). Incorrect beliefs about future pension streams could potentially have negative impacts on individual welfare due to sub-optimal consumption and saving decisions, among other things. While such ex-post evaluations are outside the scope of this study, the survey contained one question related to regret. Individuals who made decisions on pension payouts without much prior thought or those who stuck with the default option either knowingly or unknowingly may experience greater ex-post regret compared to those who made an informed decision.

In conjunction with the factor ratings, the survey participants were asked to rank on a scale from 1 to 10 the extent to which they agreed with the statement 'I am confident that I made the right choice of payout length.' I examine whether annuitants express greater feelings of regret about their payout decision and whether regret is related to awareness of their decision. Specifically, I regress a dummy variable for choosing the life annuity on the demographic variables used in Section 4.2 as well as the regret variable (standardized). I do this separately for the three samples: those who knew their payout choice, those who knew or needed a reminder to get it right, and all survey participants. The results are reported in Columns 1-3, respectively, of Table 11.

From the first column, we see that annuitants are significantly less confident that they made the right payout decision. This result is in line with Brown et al. (2011) who show that individuals who were nudged into a specific retirement plan were likely to regret their decision. Interestingly, however, the relationship becomes weaker as individuals who did not know their payout choice are added to the sample. This finding provides indicative evidence that strong nudges, such as default options, may reduce the level of ex-post regret among the less informed or less engaged individuals. There is previous evidence that people who buy annuities are happier with their decision afterwards (Mitchell et al., 2003). ${ }^{41}$

\footnotetext{
${ }^{40} \mathrm{I}$ have also reestimated the specification in Table 5 on the relationship between annuitization and individual demographics separately for men and women (not reported). Three observations are worth pointing out. First, men are driving the positive relationship between continuing to work after claiming their pensions and annuitization. Second, women are driving the positive relationship between self-reported health and annuitization. Third, women at the lower end of the income distribution are less likely to annuitize, as opposed to low-income men who are more likely to annuitize (relative to those in the middle part of the income distribution).

${ }^{41}$ I have tested the equality of the regret coefficients in columns (1)-(3) using the post-estimation command suest in Stata. Significance is sensitive to the inclusion of control variables, which implies that the results should be interpreted with caution.
} 


\section{Conclusion}

In this paper, I analyze a telephone survey of 1,000 new retirees to study awareness and motivations of pension decisions. The survey population is Swedish white-collar workers who had made pension decisions, choosing among a life annuity and several fixed-term payouts, in their occupational pension plan in 2013. The fastest rate at which the pension capital can be withdrawn is over a 5-year term. The survey was conducted in early 2014. The survey data are matched with administrative records from the managing pension company on the actual payout decisions of the survey participants. Access to actual payout decisions provides a unique opportunity to examine ex-post the extent to which retirees are able to recall their payout choice.

I find that a majority of retiring white-collar workers fail to recall their payout choice. Ignorance is much higher among annuitants; only $40 \%$ of the annuitants could accurately recall their payout choice compared to $77 \%$ of those who opted for a fixed-term payout. The most likely reason why annuitants are less informed about their payout choice is that the annuity is the default option, or the 'path of least resistance.' Beyond payout choice, however, few individual characteristics predict successful recollection.

I also find that annuitants are, on average, more likely to regret their payout choice than those who opted for a fixed-term payout. However, annuitants who were not able to recollect their payout choice when first asked but who were able to accurately report it after being informed by the interviewer do not express more regret than the informed annuitants. This observation suggests that strong nudges, such as default options, may reduce the level of ex-post regret among the less informed or less engaged individuals. In general, allowing retirees to pause or reverse initiated payments may also mitigate feelings of regret.

From an international perspective, Swedish households are financially relatively sophisticated, and white-collar workers are a positively selected group in terms of education and income. ${ }^{42}$ Yet many individuals fail to remember whether or not they recently chose to annuitize a substantial fraction of their pension wealth. How should we interpret this apparent inconsistency? My interpretation is that the low recollection rate reflects a significant body of evidence from many different countries, including Sweden, that pension plans tend to be characterized by low engagement and various behavioral biases. Individuals may refrain from making an active choice because they procrastinated until it was too late to collect the relevant information to make an informed choice, or because they did not trust their own judgement in making the right choice. Some may have even missed the opportunity of making a payout decision altogether.

Engagement in claiming decisions may increase naturally over time - younger cohorts may be more used to and susceptible to freedom of choice in their retirement savings. Compared to DB plans, which is the focus of this study, DC plans generally leave more room for individual retirement savers to make their own decisions regarding their pensions. However, policymakers and pension plan administrators also need to make sure that the choice architecture and the set of available information are designed in such a way that future retirees can easily make informed claiming decisions. For example, online tools that collect and personalize information on accumulated pension capital in different pension plans provide a promising way for retirees to get a better overview of their financial situation. In Sweden, the online platform Minpension.se ${ }^{43}$ is currently launching a device that allows individuals to plan and initiate payouts from all three pillars. Using this platform significantly reduces transaction costs in pension applications and may encourage retirees to exert more effort in making their claiming

\footnotetext{
${ }^{42}$ Sweden often ranks high in international comparisons on stock market participation, exposure to equity, and financial wealth (Swedish Investment Fund Association, 2018). Calvet et al. (2007) show that almost two-thirds of Swedish households participated in risky asset markets at the end of 2002, where mutual funds represent the largest share of risky assets for most households. They also show that a majority of Swedish households have investment portfolios that are well diversified and even outperform the Sharpe ratio of their own domestic stock index.

${ }^{43}$ Minpension.se is an online tool that helps individuals to figure out how much money they will receive once they retire. The service - a collaboration between the government and participating pension funds - currently has more than 3.8 million users.
} 
decisions. Another possibility is to change the choice architecture from choosing inputs (payout choice) to choosing outcomes (desired income profile during retirement) (Goldstein et al., 2008).

As annuitization rates in all major second-pillar pensions in Sweden are approaching 50\%, policymakers are increasingly concerned that many individuals will be at risk of outliving their resources. The trend towards shorter payouts is likely to continue as replacement rates in the first pillar continue to fall, and as the share of second-pillar pension wealth that is not subject to mandatory annuitization increases. Furthermore, while today's retirees tend to have a small number of fairly large pension capital stocks, rising worker mobility across sectors implies that tomorrow's retirees are more likely to have a larger number of small pension capital stocks, which in turn could lead to lower annuitization rates. I have documented in this paper that small stocks of pension capital are more likely to be cashed out. The most common self-reported motivation for taking a fixed-term payout is a desire to spend more in the early years of retirement. Many also express a willingness to 'cash out the money before dying.' Partial annuitization or bonus payments might therefore be effective in increasing annuitization rates, as argued by Beshears et al. (2014) and Bockweg et al. (2018). Future research in this field should continue to map trends in annuitization rates across different sectors and countries, and in particular, focus on the later-life consequences of choosing a lump-sum or fixed-term payout, and of potential misbeliefs of past pension decisions.

Acknowledgement. Thanks to Alecta for financially supporting and administrating the survey and to two anonymous referees for providing useful and constructive comments. Financial support from Forte (nr 2017-00092 and 2013-2482) is gratefully acknowledged.

\section{References}

Agnew JR, Anderson LR, Gerlach JR and Szykman LR (2008) Who chooses annuities? An experimental investigation of the role of gender, framing, and defaults. American Economic Review 98, 418-422.

Agnew JR, Anderson LR and Szykman LR (2015) An experimental study of the effect of market performance on annuitization and equity allocations. Journal of Behavioral Finance 16, 120-129.

Alexandrova M and Gatzert N (2019) What do we know about annuitization decisions? Risk Management and Insurance Review 22, 57-100.

Almenberg J and Säve-Söderbergh J (2011) Financial literacy and retirement planning in Sweden. Journal of Pension Economics \& Finance 10, 585-598.

Almenberg J, Lusardi A, Säve-Söderbergh J and Vestman R (2020) Attitudes toward debt and debt behavior. CEPR Discussion Paper 14801.

AMF (2018) AMF Pensionsrapport 2018/19. Available at https://www.amf.se/pressrum/rapporter-fakta/. Online; accessed 20 April 2019.

Antolin P (2008) Policy options for the payout phase. OECD Working Papers on Insurance and Private Pensions, No.25.

Banerjee S (2013) Annuity and lump-sum decisions in defined benefit plans: the role of plan rules. EBRI Issue Brief, (381).

Banks J, Crawford R and Tetlow G (2015) Annuity choices and income drawdown: evidence from the decumulation phase of defined contribution pensions in England. Journal of Pension Economics \& Finance 14, 412-438.

Barr N and Diamond P (2008) Reforming Pensions: Principles and Policy Choices. Oxford: Oxford University Press.

Benartzi S, Previtero A and Thaler RH (2011) Annuitization puzzles. Journal of Economic Perspectives 25, $143-164$.

Beshears J, Choi JJ, Laibson D, Madrian BC and Zeldes SP (2014) What makes annuitization more appealing? Journal of Public Economics 116, 2-16.

Bockweg C, Ponds E, Steenbeek O and Vonken J (2018) Framing and the annuitization decision: experimental evidence from a Dutch pension fund. Journal of Pension Economics \& Finance 17, 385-417.

Böhnke M, Brüggen E and Post T (2019) Appreciated but complicated pension choices? Insights from the Swedish premium pension system. Available at http://dx.doi.org/10.2139/ssrn.3208077.

Brown JR (2001) Private pensions, mortality risk, and the decision to annuitize. Journal of Public Economics 82, $29-62$.

Brown JR and Poterba JM (2000) Joint life annuities and annuity demand by married couples. Journal of Risk and Insurance 67, 527-553.

Brown JR and Previtero A (2020) Saving for retirement, annuities and procrastination. Mimeo, Accessed 23 June 2020.

Brown JR, Kling JR, Mullainathan S and Wrobel MV (2008) Why don't people insure late-life consumption? A framing explanation of the under-annuitization puzzle. American Economic Review 98, 304-309.

Brown JR, Farrell AM and Weisbenner SJ (2011) The downside of defaults. Working Paper 20949, National Bureau of Economic Research. 
Brown JR, Ivković Z and Weisbenner S (2015) Empirical determinants of intertemporal choice. Journal of Financial Economics 116, 473-486.

Bütler M and Ramsden A (2017) How taxes impact the choice between an annuity and the lump sum at retirement. Economics Working Paper Series, 1701.

Bütler M and Teppa F (2007) The choice between an annuity and a lump sum: results from Swiss pension funds. Journal of Public Economics 91, 1944-1966.

Bütler M, Staubli S and Zito MG (2013) How much does annuity demand react to a large price change? Scandinavian Journal of Economics 115, 808-824.

Bütler M, Peijnenburg K and Staubli S (2017) How much do means-tested benefits reduce the demand for annuities? Journal of Pension Economics \& Finance 16, 419-449.

Calvet LE, Campbell JY and Sodini P (2007) Down or out: assessing the welfare costs of household investment mistakes. Journal of Political Economy 115, 707-747.

Cappelletti G, Guazzarotti G and Tommasino P (2013) What determines annuity demand at retirement? The Geneva Papers on Risk and Insurance-Issues and Practice 38, 777-802.

Chalmers J and Reuter J (2012) How do retirees value life annuities? Evidence from public employees. Review of Financial Studies 25, 2601-2634.

Choi JJ, Laibson D, Madrian BC and Metrick A (2002) Defined contribution pensions: plan rules, participant choices, and the path of least resistance. Tax policy and the Economy 16, 67-113.

Choi JJ, Laibson D, Madrian BC and Metrick A (2003) Optimal defaults. American Economic Review 93, 180-185.

Cronqvist $\mathbf{H}$ and Thaler RH (2004) Design choices in privatized social-security systems: learning from the Swedish experience. American Economic Review 94, 424-428.

Cronqvist H, Thaler RH and Yu F (2018) When nudges are forever: Inertia in the swedish premium pension plan. $A E A$ Papers and Proceedings 108, 153-158.

Dahlquist M and Martinez JV (2015) Investor inattention: a hidden cost of choice in pension plans? European Financial Management 21, 1-19.

Davidoff T, Brown JR and Diamond PA (2005) Annuities and individual welfare. American Economic Review 95, 15731590.

Finkelstein A and Poterba J (2002) Selection effects in the United Kingdom individual annuities market. The Economic Journal 112, 28-50.

Finkelstein A and Poterba J (2004) Adverse selection in insurance markets: policyholder evidence from the UK annuity market. Journal of Political Economy 112, 183-208.

Frederick S, Loewenstein G and O'donoghue T (2002) Time discounting and time preference: a critical review. Journal of economic literature 40, 351-401.

Friedman BM and Warshawsky M (1988). Annuity prices and saving behavior in the United States. In Bodie Z, Shoven JB and Wise DA (eds), Pensions in the US Economy. Chicago: University of Chicago Press, pp. 53-84.

Goedde-Menke M, Lehmensiek-Starke M and Nolte S (2014) An empirical test of competing hypotheses for the annuity puzzle. Journal of Economic Psychology 43, 75-91.

Goldstein DG, Johnson EJ and Sharpe WF (2008) Choosing outcomes versus choosing products: consumer-focused retirement investment advice. Journal of Consumer Research 35, 440-456.

Hagen J (2013) A history of the Swedish pension system. UCFS Working Paper No. 2013:7, Uppsala University.

Hagen J (2015) The determinants of annuitization: evidence from Sweden. International Tax and Public Finance 22, 549-578.

Hagen J (2017a) Pension principles in the Swedish pension system. Scandinavian Economic History Review 65, 28-51.

Hagen J (2017b) Utbetalningstider i tjänstepensionssystemet. Stockholm: SNS förlag.

Hagen J, Hallberg D and Sjögren Lindquist G (2018) A nudge to quit? The effect of a change in pension information on annuitization, labor supply and retirement choices among older workers. GLO Discussion Paper 209.

Hu W-Y and Scott JS (2007) Behavioral obstacles in the annuity market. Financial Analysts Journal 63, 71-82.

Hurd M and Panis C (2006) The choice to cash out pension rights at job change or retirement. Journal of Public Economics 90, 2213-2227.

Hurd MD and Rohwedder S (2011) Economic preparation for retirement. In Wise DA (ed.), Investigations in the Economics of Aging. Chicago: University of Chicago Press, pp. 77-113.

Inkmann J, Lopes P and Michaelides A (2011) How deep is the annuity market participation puzzle? Review of Financial Studies 24, 279-319.

ISF (2015) Att välja uttagstid av tjänstepension. Rapport 2015:15, Stockholm: Inspektionen för socialförsäkringen.

ISF (2017) Tidsbegränsade uttag av tjänstepensioner och låg ekonomisk standard. Rapport 2017:1, Stockholm: Inspektionen för socialförsäkringen.

ISF (2018) Tidsbegränsade uttag av tjänstepension bland kvinnor och män. Rapport 2018:15, Stockholm: Inspektionen för socialförsäkringen. 
James E, Martinez G and Iglesias A (2006) The payout stage in Chile: who annuitizes and why? Journal of Pension Economics \& Finance 5, 121-154.

Kjellberg A (2018) Kollektivavtalens täckningsgrad samt organisationsgraden hos arbetsgivarförbund och fackförbund. Studies in Social Policy, Industrial Relations, Working Life and Mobility Vol. 2018, Nr. 1, Department of Sociology, Lund University.

Knoller C (2016) Multiple reference points and the demand for principal-protected life annuities: an experimental analysis. Journal of Risk and Insurance 83(1), 163-179.

Lee K (2016) Analysis of payout choice from individual deferred annuities in Korea. Journal of Pension Economics \& Finance 15(2), 224-248.

Lusardi A and Mitchell OS (2014) The economic importance of financial literacy: theory and evidence. Journal of Economic Literature 52(1), 5-44.

Mitchell OS, Poterba JM, Warshawsky MJ and Brown JR (1999) New evidence on the money's worth of individual annuities. American Economic Review 89(5), 1299-1318.

Mottola GR and Utkus SP (2007) Lump sum or annuity? An analysis of choice in DB pension payouts. Vanguard Center for Retirement Research 30, 2.

Palme M, Sundén AE and Söderlind P (2007). Investment choice in the Swedish premium pension plan. Journal of the European Economic Association Papers and Proceedings 5, 636-646.

Palmer E and Larsson B (2011) The Swedish annuity market: Where it is and where it's headed. In Mitchell OS, Piggott J and Takayama N (eds), Securing Lifelong Retirement Income: Global Annuity Markets and Policy. Oxford: Oxford University Press, pp. 13-31.

Panis CWA, (2003) Annuities and Retirement Well-Being. In Mitchell OS and Utkus SP (eds), Design and Structure: New Lessons From Behavioral Finance. New York: Oxford University Press, pp. 259-274.

Park Y and Banerjee S (2020) Coworker influence on annuitization decisions: evidence from defined benefit plans. Journal of Economic Behavior \& Organization 178, 582-606.

Previtero A (2014) Stock market returns and annuitization. Journal of Financial Economics 113, 202-214.

Reichling F and Smetters K (2015) Optimal annuitization with stochastic mortality and correlated medical costs. American Economic Review 105, 3273-3320.

Swedish Investment Fund Association (2018) Det svenska fondsparandet ur ett internationellt perspektiv - en översikt. Available at https://www.fondbolagen.se/globalassets/faktaindex/studier-o-undersokningar/det-svenska-fondsparandetur-ett-internationellt-perspektiv-2018.pdf.

Thaler R (1985) Mental accounting and consumer choice. Marketing Science 4, 199-214.

Yaari ME (1965) Uncertain lifetime, life insurance, and the theory of the consumer. Review of Economic Studies 32, 137-150. 


\section{Appendix}

Table A1. Demographic correlates of correct belief, pooled sample

\begin{tabular}{|c|c|c|}
\hline & \multicolumn{2}{|c|}{ (1) } \\
\hline Female & -0.0324 & $(0.0513)$ \\
\hline Married & -0.0303 & $(0.0572)$ \\
\hline Number of children & 0.00953 & $(0.0191)$ \\
\hline Work 1 day or less per week & -0.0108 & $(0.0620)$ \\
\hline Work several days or more per week & $-0.114^{\star \star}$ & $(0.0541)$ \\
\hline On sick leave prior to retirement & -0.0344 & $(0.0729)$ \\
\hline Homeowner & -0.0165 & $(0.0643)$ \\
\hline \multicolumn{3}{|l|}{ ITP pension capital rank } \\
\hline$<\mathrm{p} 10$ & $0.144^{\star}$ & $(0.0774)$ \\
\hline p10-p30 & -0.0289 & $(0.0600)$ \\
\hline p70-p90 & -0.0221 & $(0.0627)$ \\
\hline$>$ p 90 & $0.165^{\star \star}$ & $(0.0799)$ \\
\hline \multicolumn{3}{|l|}{ Pre-retirement income rank } \\
\hline$<p 10$ & -0.0922 & $(0.0767)$ \\
\hline p10-p30 & 0.000356 & $(0.0611)$ \\
\hline p70-p90 & 0.0686 & $(0.0685)$ \\
\hline$>$ p90 & 0.0289 & $(0.0920)$ \\
\hline \multicolumn{3}{|l|}{ Highest education attained } \\
\hline High school & 0.00975 & $(0.0620)$ \\
\hline College (or higher) & 0.00349 & $(0.0648)$ \\
\hline Financially literate ( 3 out of 3 ) & -0.0298 & $(0.0444)$ \\
\hline Talked to financial advisor & -0.0107 & $(0.0419)$ \\
\hline Self-reported health (1-10) & -0.0122 & $(0.0126)$ \\
\hline Do not think about future $(1-10)$ & -0.0111 & $(0.00745)$ \\
\hline Likes taking risks $(1-10)$ & 0.00406 & $(0.0113)$ \\
\hline Trust in pension providers $(1-10)$ & 0.00531 & $(0.00840)$ \\
\hline Frequent trader $(1-10)$ & 0.00443 & $(0.00901)$ \\
\hline Constant & $0.657^{\star \star \star}$ & $(0.161)$ \\
\hline Observations & 800 & \\
\hline
\end{tabular}

* Significant at the $10 \%$ level. ** Significant at the $5 \%$ level. *** Significant at the $1 \%$ level.

The $p$-value from an overall $F$-test of the joint significance of the pension capital rank variables is 0.04 . The corresponding $p$-value for the pre-retirement income rank variables is 0.73 .

This table reports the coefficient estimates from a linear probability model regressing a dummy variable that takes on the value of 1 if the individual reports the payout option that he or she actually chose on a set of independent variables. Inverse sampling probabilities were used. Robust standard errors are in parentheses. 
Table A2. Demographic correlates of annuitization, extended samples

\begin{tabular}{|c|c|c|c|c|}
\hline \multirow[b]{3}{*}{ Female } & \multicolumn{2}{|c|}{$(1)$} & \multicolumn{2}{|c|}{$(2)$} \\
\hline & \multicolumn{2}{|c|}{ Knew/Needed reminder } & \multicolumn{2}{|c|}{ Everyone } \\
\hline & -0.0275 & $(0.0428)$ & -0.0150 & $(0.0351)$ \\
\hline Married & -0.0258 & $(0.0485)$ & 0.0176 & $(0.0398)$ \\
\hline Number of children & -0.000517 & $(0.0160)$ & 0.00166 & $(0.0127)$ \\
\hline Work 1 day or less per week & -0.00805 & $(0.0528)$ & 0.00751 & $(0.0428)$ \\
\hline Work several days or more per week & $0.0866^{\star *}$ & $(0.0421)$ & $0.120^{\star \star \star}$ & $(0.0316)$ \\
\hline On sick leave prior to retirement & 0.00175 & $(0.0731)$ & 0.0528 & $(0.0548)$ \\
\hline Homeowner & 0.00971 & $(0.0536)$ & 0.0181 & $(0.0445)$ \\
\hline \multicolumn{5}{|l|}{ ITP pension capital rank } \\
\hline$<p 10$ & $-0.123^{\star}$ & $(0.0709)$ & $-0.110^{\star}$ & $(0.0583)$ \\
\hline p10-p30 & $-0.111^{\star}$ & $(0.0609)$ & -0.0522 & $(0.0466)$ \\
\hline p70-p90 & $0.114^{\star *}$ & $(0.0467)$ & $0.103^{\star \star \star}$ & $(0.0373)$ \\
\hline$>$ p90 & $0.210^{\star \star \star}$ & $(0.0511)$ & $0.189^{\star \star \star}$ & $(0.0421)$ \\
\hline \multicolumn{5}{|l|}{ Pre-retirement income rank } \\
\hline$<p 10$ & 0.0660 & $(0.0679)$ & 0.0596 & $(0.0563)$ \\
\hline p10-p30 & 0.00823 & $(0.0537)$ & 0.0307 & $(0.0437)$ \\
\hline p70-p90 & -0.00883 & $(0.0488)$ & -0.00501 & $(0.0388)$ \\
\hline$>$ p 90 & $0.0991^{\star}$ & $(0.0582)$ & -0.00189 & $(0.0489)$ \\
\hline \multicolumn{5}{|l|}{ Highest education attained } \\
\hline High school & $0.107^{\star}$ & $(0.0586)$ & 0.0762 & $(0.0473)$ \\
\hline College (or higher) & $0.149^{\star \star}$ & $(0.0590)$ & $0.124^{\star \star \star}$ & $(0.0475)$ \\
\hline Financially literate ( 3 out of 3 ) & -0.00596 & $(0.0378)$ & 0.0197 & $(0.0301)$ \\
\hline Talked to financial advisor & $-0.0987^{\star \star}$ & $(0.0404)$ & $-0.0676^{\star \star}$ & $(0.0284)$ \\
\hline Self-reported health (1-10) & 0.0166 & $(0.0118)$ & $0.0167^{\star}$ & $(0.00978)$ \\
\hline Do not think about future $(1-10)$ & 0.00798 & $(0.00622)$ & 0.00500 & $(0.00485)$ \\
\hline Likes taking risks $(1-10)$ & 0.0102 & $(0.00974)$ & 0.00538 & $(0.00735)$ \\
\hline Trust in pension providers $(1-10)$ & 0.0118 & $(0.00763)$ & 0.00459 & $(0.00577)$ \\
\hline Frequent trader $(1-10)$ & $-0.0255^{\star \star \star}$ & $(0.00798)$ & $-0.0193^{\star \star \star}$ & $(0.00630)$ \\
\hline Constant & $0.355^{\star \star}$ & $(0.152)$ & $0.403^{\star \star \star}$ & $(0.122)$ \\
\hline Observations & 678 & & 844 & \\
\hline$R^{2}$ & 0.119 & & 0.083 & \\
\hline
\end{tabular}

* Significant at the $10 \%$ level. ** Significant at the $5 \%$ level. ${ }^{\star \star \star}$ Significant at the $1 \%$ level.

This table reports the coefficient estimates from a linear probability model regressing a dummy variable that takes on the value of 1 if the individual chooses the life annuity on a set of independent variables. The sample in column (1) is restricted to individuals who knew their payout choice or needed a reminder to get it right. The sample in column (2) includes all survey participants. Inverse sampling probabilities were used. Robust standard errors are in parentheses. 
Table A3. Factor ratings, needed reminder

\begin{tabular}{|c|c|c|c|c|}
\hline \multirow[b]{3}{*}{ Tax reasons } & \multicolumn{2}{|c|}{$(1)$} & \multicolumn{2}{|c|}{$(2)$} \\
\hline & \multicolumn{2}{|c|}{ Life annuity } & \multicolumn{2}{|c|}{ Life annuity } \\
\hline & 0.00240 & $(0.0189)$ & -0.0134 & $(0.0325)$ \\
\hline Work several days or more per week & & & -0.0448 & $(0.0470)$ \\
\hline College (or higher) & & & 0.0405 & $(0.0451)$ \\
\hline Above median pre-retirement income & & & 0.0421 & $(0.0536)$ \\
\hline Above median pension capital & & & -0.000904 & $(0.0474)$ \\
\hline Talked to financial advisor & & & 0.00800 & $(0.0455)$ \\
\hline In need of money at retirement & $0.0401^{*}$ & $(0.0208)$ & $0.0784^{\star \star}$ & $(0.0304)$ \\
\hline Work several days or more per week & & & -0.0152 & $(0.0495)$ \\
\hline College (or higher) & & & -0.0178 & $(0.0435)$ \\
\hline Above median pre-retirement income & & & 0.0950 & $(0.104)$ \\
\hline Above median pension capital & & & -0.0616 & $(0.0520)$ \\
\hline Talked to financial advisor & & & -0.0743 & $(0.0476)$ \\
\hline Important that pension secures old-age consumption & 0.0152 & $(0.0233)$ & -0.0194 & $(0.0348)$ \\
\hline Work several days or more per week & & & 0.0861 & $(0.0564)$ \\
\hline College (or higher) & & & 0.0694 & $(0.0478)$ \\
\hline Above median pre-retirement income & & & -0.0708 & $(0.0561)$ \\
\hline Above median pension capital & & & $0.142^{\star \star}$ & $(0.0561)$ \\
\hline Talked to financial advisor & & & -0.0580 & $(0.0472)$ \\
\hline Invest money on my own & 0.00281 & $(0.0208)$ & 0.00779 & $(0.0323)$ \\
\hline Work several days or more per week & & & 0.0578 & $(0.0578)$ \\
\hline College (or higher) & & & -0.0323 & $(0.0481)$ \\
\hline Above median pre-retirement income & & & -0.0423 & $(0.0808)$ \\
\hline Above median pension capital & & & -0.0131 & $(0.0576)$ \\
\hline Talked to financial advisor & & & 0.0337 & $(0.0476)$ \\
\hline Leave an inheritance & -0.00982 & $(0.0199)$ & -0.00839 & $(0.0327)$ \\
\hline Work several days or more per week & & & 0.0163 & $(0.0523)$ \\
\hline College (or higher) & & & -0.0544 & $(0.0481)$ \\
\hline Above median pre-retirement income & & & -0.0455 & $(0.0888)$ \\
\hline Above median pension capital & & & 0.0536 & $(0.0532)$ \\
\hline Talked to financial advisor & & & 0.0619 & $(0.0454)$ \\
\hline Want to cash out money before I die & $-0.0567^{\star \star \star}$ & $(0.0166)$ & -0.0384 & $(0.0295)$ \\
\hline Work several days or more per week & & & -0.0470 & $(0.0429)$ \\
\hline College (or higher) & & & 0.0248 & $(0.0373)$ \\
\hline Above median pre-retirement income & & & 0.0514 & $(0.0644)$ \\
\hline Above median pension capital & & & -0.0485 & $(0.0433)$ \\
\hline Talked to financial advisor & & & -0.0564 & $(0.0368)$ \\
\hline There was a recommended payout option that I chose & $0.0643^{\star \star \star}$ & $(0.0181)$ & $0.0899^{\star \star *}$ & $(0.0310)$ \\
\hline Work several days or more per week & & & $-0.118^{\star \star \star}$ & $(0.0445)$ \\
\hline College (or higher) & & & 0.00582 & $(0.0415)$ \\
\hline Above median pre-retirement income & & & -0.0123 & $(0.0737)$ \\
\hline Above median pension capital & & & 0.0737 & $(0.0629)$ \\
\hline Talked to financial advisor & & & -0.0373 & $(0.0434)$ \\
\hline Observations & 622 & & 622 & \\
\hline
\end{tabular}

\footnotetext{
* Significant at the $10 \%$ level. ** Significant at the $5 \%$ level. ${ }^{* \star *}$ Significant at the $1 \%$ level.
}

This table reports the coefficient estimates from a linear probability model regressing a dummy variable that takes on the value of 1 if the individual chooses the life annuity on participants' factor ratings. The factor ratings are standardized to have a mean of zero and a variance of one. Columns (1) and (2) control for the demographic variables in Table 5. Column (2) adds interaction terms between each factor rating and several individual characteristics. The sample is restricted to individuals who knew their payout choice or needed a reminder to get it right. Inverse sampling probabilities were used. Robust standard errors are in parentheses. 
Table A4. Factor ratings, everyone

(2)

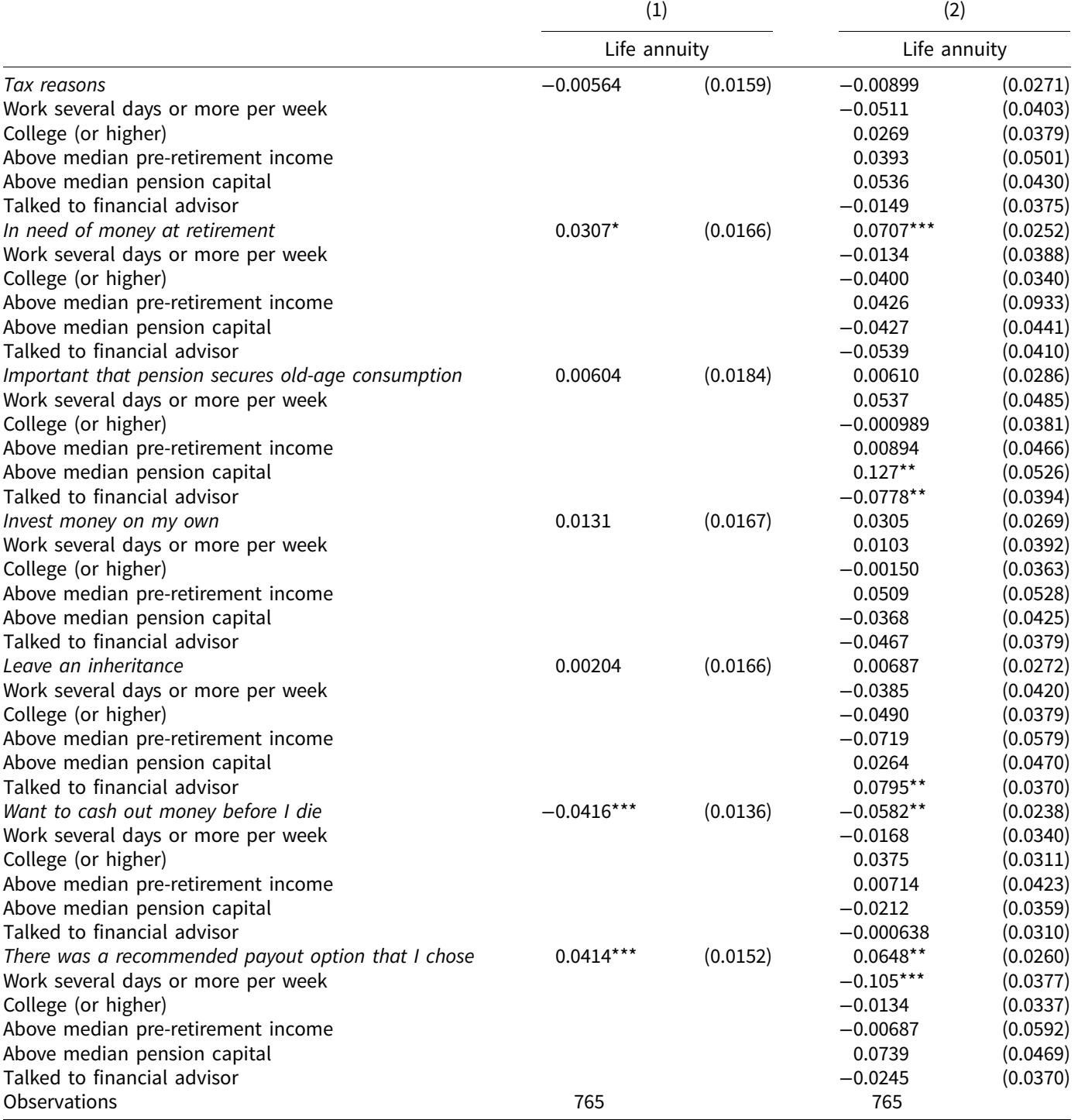

* Significant at the $10 \%$ level. ${ }^{* *}$ Significant at the $5 \%$ level. ${ }^{* \star *}$ Significant at the $1 \%$ level.

This table reports the coefficient estimates from a linear probability model regressing a dummy variable that takes on the value of 1 if the individual chooses the life annuity on participants' factor ratings. The factor ratings are standardized to have a mean of zero and a variance of one. Columns (1) and (2) control for the demographic variables in Table 5. Column (2) adds interaction terms between each factor rating and several individual characteristics. The sample includes all survey participants. Inverse sampling probabilities were used. Robust standard errors are in parentheses. 
Table A5. Demographic correlates of annuitization using a multinomial logit model (marginal effects), needed reminder

\begin{tabular}{|c|c|c|c|c|c|c|}
\hline \multirow[b]{2}{*}{ Female } & \multicolumn{2}{|c|}{5 years } & \multicolumn{2}{|c|}{10 years } & \multicolumn{2}{|c|}{$15 / 20$ years } \\
\hline & 0.045 & $(0.040)$ & -0.001 & $(0.034)$ & -0.029 & $(0.025)$ \\
\hline Married & -0.016 & $(0.046)$ & 0.057 & $(0.036)$ & -0.047 & $(0.037)$ \\
\hline Number of children & 0.014 & $(0.016)$ & -0.020 & $(0.014)$ & 0.011 & $(0.010)$ \\
\hline Work 1 day or less per week & 0.003 & $(0.051)$ & 0.018 & $(0.044)$ & -0.031 & $(0.029)$ \\
\hline Work several days or more per week & $-0.086^{\star}$ & $(0.045)$ & -0.007 & $(0.040)$ & -0.012 & $(0.029)$ \\
\hline On sick leave prior to retirement & -0.063 & $(0.058)$ & $0.106^{*}$ & $(0.059)$ & -0.054 & $(0.033)$ \\
\hline Homeowner & 0.023 & $(0.051)$ & -0.045 & $(0.047)$ & 0.038 & $(0.033)$ \\
\hline \multicolumn{7}{|l|}{ ITP pension capital rank } \\
\hline$<$ p10 & $0.318^{\star \star \star}$ & $(0.060)$ & $-0.138^{\star \star \star}$ & $(0.036)$ & $-0.115^{\star \star \star}$ & $(0.012)$ \\
\hline p10-p30 & 0.077 & $(0.049)$ & 0.067 & $(0.041)$ & $-0.076^{\star \star \star}$ & $(0.025)$ \\
\hline p70-p90 & -0.056 & $(0.050)$ & $-0.125^{\star \star \star}$ & $(0.034)$ & 0.040 & $(0.032)$ \\
\hline$>$ p90 & $-0.232^{\star * *}$ & $(0.057)$ & $-0.156^{\star \star \star}$ & $(0.037)$ & 0.079 & $(0.048)$ \\
\hline \multicolumn{7}{|l|}{ Pre-retirement income rank } \\
\hline$<p 10$ & -0.016 & $(0.059)$ & -0.022 & $(0.047)$ & -0.018 & $(0.043)$ \\
\hline p10-p30 & 0.042 & $(0.048)$ & -0.023 & $(0.039)$ & $-0.050^{\star}$ & $(0.028)$ \\
\hline p70-p90 & 0.019 & $(0.056)$ & 0.018 & $(0.050)$ & -0.039 & $(0.026)$ \\
\hline$>$ p90 & $-0.133^{\star}$ & $(0.079)$ & 0.071 & $(0.081)$ & $-0.058^{\star \star}$ & $(0.029)$ \\
\hline \multicolumn{7}{|l|}{ Highest education attained } \\
\hline High school & -0.014 & $(0.048)$ & $-0.083^{\star \star}$ & $(0.037)$ & 0.012 & $(0.034)$ \\
\hline College (and higher) & -0.048 & $(0.051)$ & $-0.097^{\star \star}$ & $(0.039)$ & 0.009 & $(0.036)$ \\
\hline Financially literate ( 3 out of 3 ) & -0.031 & $(0.036)$ & -0.018 & $(0.030)$ & $0.053^{\star \star}$ & $(0.023)$ \\
\hline Talked to financial advisor & $0.080^{\star \star}$ & $(0.035)$ & 0.015 & $(0.030)$ & -0.003 & $(0.023)$ \\
\hline Self-reported health (1-10) & -0.015 & $(0.009)$ & -0.001 & $(0.008)$ & -0.003 & $(0.006)$ \\
\hline Do not think about future $(1-10)$ & -0.003 & $(0.006)$ & -0.002 & $(0.005)$ & -0.003 & $(0.004)$ \\
\hline Likes taking risks $(1-10)$ & 0.006 & $(0.009)$ & -0.002 & $(0.008)$ & $-0.010^{\star}$ & $(0.006)$ \\
\hline Trust in pension providers $(1-10)$ & $-0.015^{\star \star}$ & $(0.007)$ & 0.002 & $(0.006)$ & 0.001 & $(0.005)$ \\
\hline Frequent trader $(1-10)$ & -0.009 & $(0.007)$ & $0.019^{\star \star \star}$ & $(0.005)$ & $0.014^{\star \star \star}$ & $(0.004)$ \\
\hline Observations & 678 & & 678 & & 678 & \\
\hline
\end{tabular}

* Significant at the $10 \%$ level. ${ }^{* \star}$ Significant at the $5 \%$ level. ${ }^{\star \star \star}$ Significant at the $1 \%$ level.

This table reports marginal effects estimated using a multinomial logit model. The marginal effect associated with each coefficient can be interpreted as the variable's incremental effect on the probability of choosing the fixed-term payout indicated in the column heading. Note that 15- and 20-year payouts have been merged into one category. The life annuity is the reference category. The sample is restricted to those who either knew their payout choice or needed a reminder to get it right.

Table A6. Self-reported reason for choosing a fixed-term payout, by gender

\begin{tabular}{lrrrrrr}
\hline & \multicolumn{3}{c}{ Women } & & \multicolumn{3}{c}{ Men } \\
\cline { 2 - 6 } & \multicolumn{1}{c}{5} & 10 & $15 / 20$ & 5 & 10 & $15 / 20$ \\
\hline Annuity too small & 16.9 & 14.1 & 15.4 & 12.1 & 7.5 & 2.2 \\
Invest money on my own & 6.5 & 9.4 & 15.4 & 11.2 & 7.5 & 8.9 \\
Consumption flexibility & 36.3 & 42.2 & 30.8 & 37.4 & 47.8 & 57.8 \\
Cash out money before I die & 25.0 & 12.5 & 7.7 & 21.5 & 14.9 & 20.0 \\
Bequest motives & 3.2 & 1.6 & 0.0 & 4.7 & 1.5 & 0.0 \\
Poor health/low life expectancy & 6.5 & 9.4 & 15.4 & 5.6 & 11.9 & 11.1 \\
Advised by friend or expert & 2.4 & 4.7 & 0.0 & 5.6 & 3.0 & 0.0 \\
No particular reason & 3.2 & 6.3 & 15.4 & 1.9 & 6.0 & 0.0 \\
Observations & 124 & 64 & 13 & 107 & 67 & 45 \\
\hline
\end{tabular}

This table reports the distribution (in \%) of the self-reported main reasons for choosing the fixed-term payout indicated in the column heading. Note that 15- and 20-year payouts have been merged into one category. The responses were categorized into the relevant groups by the author. 
Table A7. Self-reported reason for choosing a fixed-term payout, extended samples

\begin{tabular}{lrrrrrr}
\hline & \multicolumn{3}{c}{ Knew/Needed reminder } & & \multicolumn{2}{c}{ All } \\
\cline { 2 - 6 } & \multicolumn{1}{c}{5} & 10 & $15 / 20$ & 5 & 10 & $15 / 20$ \\
\cline { 2 - 6 } & 15.2 & 10.4 & 6.8 & 14.6 & 10.5 & 5.7 \\
Annuity too small & 10.0 & 9.1 & 10.8 & 10.0 & 8.6 & 11.5 \\
Invest money on my own & 35.9 & 45.5 & 48.6 & 36.3 & 45.7 & 50.6 \\
Consumption flexibility & 23.0 & 14.3 & 16.2 & 22.8 & 14.2 & 13.8 \\
Cash out money before I die & 3.7 & 1.3 & 1.4 & 3.9 & 2.5 & 1.1 \\
Bequest motives & 5.6 & 9.7 & 9.5 & 5.7 & 9.3 & 10.3 \\
Poor health/low life expectancy & 3.3 & 3.2 & 0.0 & 3.2 & 3.1 & 0.0 \\
Advised by friend or expert & 3.3 & 6.5 & 6.8 & 3.6 & 6.2 & 6.9 \\
No particular reason & 270 & 154 & 74 & 281 & 162 & 87 \\
Observations & &
\end{tabular}

This table reports the distribution (in \%) of the self-reported main reasons for choosing the fixed-term payout indicated in the column heading. Note that 15- and 20-year payouts have been merged into one category. The responses were categorized into the relevant groups by the author. The sample in the first three columns is restricted to individuals who knew their payout choice or needed a reminder to get it right. The sample in the three last columns contains all survey participants.

Cite this article: Hagen J (2022). Partial recall: differences between actual and self-reported annuitization decisions in Sweden. Journal of Pension Economics and Finance 21, 375-404. https://doi.org/10.1017/S1474747220000372 